\title{
THE SUITABILITY OF IRB LIABILITY
}

\author{
Sharona Hoffman ${ }^{*} \&$ Jessica Wilen Berg ${ }^{* *}$
}

\begin{abstract}
The biomedical research oversight system in the United States delegates most responsibilities to local review entities known as institutional review boards (IRBS). The IRBs are charged with responsibility for safeguarding the welfare of research participants and ensuring that clinical studies involving human subjects comply with federal regulations.

During the past three decades, the United States has experienced a dramatic proliferation of biomedical research studies. Contemporary critics often voice serious concerns about the adequacy of the regulations as a mechanism to ensure the safety of study participants.

Several lawsuits in recent years have named IRBs and IRB members as defendants, and these may portend a future fraught with litigation against IRBs. Such litigation poses new challenges for the IRB oversight system, including difficulty in recruiting IRB members, increased research costs, and potential over-deterrence that may adversely affect IRB deliberations and decision-making. Frequent litigation, therefore, could have profound implications for the research community that should be considered and addressed proactively.

This article argues that retroactive review can be a useful adjunct to prospective oversight, but that it should be limited in scope. First, we recommend that all claims against IRBs be brought before the Food and Drug Administration (FDA) or the Department of Health and Human Services (HHS) for mandatory administrative review prior to the commencement of

* Professor of Law, Professor of Bioethics, and Associate Director of the Law-Medicine Center, Case Western Reserve University School of Law. B.A., Wellesley College; J.D., Harvard Law School; LL.M. in Health Law, University of Houston. Professor Hoffman is a member of an institutional review board (IRB) in Cleveland, Ohio.

** Professor of Law and Bioethics, Case Western Reserve University Schools of Law and Medicine. B.A. and J.D., Cornell University. Professor Berg has been a member of a number of different IRBs. Research on this paper was made possible in part by support from the U.S. National Institutes of Health through the Case Western Reserve University Center for Genetic Research Ethics and Law (NIH grant \# P50 HG-003390). The authors would like to thank Carl Coleman, Jonathan Entin, Haavi Morreim, and Richard Saver for their comments on earlier drafts. All errors and omissions are the authors' own.
\end{abstract}


litigation. Such review would serve a useful gatekeeping role by filtering out or deterring frivolous actions and by resolving some claims quickly, privately, and efficiently. Second, for cases that advance to the courthouse, we recommend that IRB members be given qualified immunity similar to that available for peer reviewers under the Health Care Quality Improvement Act of 1986 (HCQIA). IRB members should be immune from liability for civil damages so long as they had a good faith belief that the challenged decision protected the welfare of human subjects and so long as they complied with all federal regulatory requirements concerning protocol review. These safeguards should promote both the welfare of human subjects and the integrity of the oversight system.

\section{INTRODUCTION}

The research oversight system in the United States delegates most responsibilities to local review entities known as institutional review boards (IRBs). ${ }^{1}$ Currently, there are between 3000 and 5000 IRBs in the United States. ${ }^{2}$ The IRBs are charged with responsibility for safeguarding the welfare of research participants and ensuring that clinical studies involving human subjects comply with federal regulations established by the Department of Health and Human Services (HHS) and the Food and Drug Administration (FDA). ${ }^{3}$

During the past three decades, the United States has experienced a dramatic proliferation of biomedical research studies. ${ }^{4}$ Consequently, the number of research projects conducted in this country has risen sharply, ${ }^{5}$ and

1. See 21 C.F.R. $\S 56.109$ (2005); 45 C.F.R. $\S 46.109$ (2005).

2. Office of Inspector Gen., Dep't of Health and Human Servis, Protecting Human Research Subjects: Status of Recommendations 20 (2000), available at 2000 WL 553517 [hereinafter 2000 OIG REPORT]. The majority are associated with hospitals and academic institutions. Other IRBs exist in managed care organizations, government agencies, or as independent for-profit entities. $I d$. at 20-21. Because there is no central registry of IRBs, it is impossible to ascertain their exact number. William J. Burman et al., Breaking the Camel's Back: Multicenter Clinical Trials and Local Institutional Review Boards, 134 Annals Internal Med. 152, 152 (2001); see also Robert Steinbrook, Public Registration of Clinical Trials, 351 NEw ENG. J. MED. 315, 315 (2004) (arguing that clinical trials should be publicly registered).

3. $\quad$ See 21 C.F.R. $\S 56.101-.109$ (2005); 45 C.F.R. $\S 46.103-.109$ (2005).

4. See Mary R. Anderlik \& Nanette Elster, Lawsuits Against IRBs: Accountability or Incongruity?, 29 J.L. MED. \& ETHICs 220, 223 (2001).

5. It is estimated that 60,000 to 70,000 clinical trials are being conducted at any given time in the United States. Elizabeth Austin, Flying Double-Blind: Would You Be Willing to Risk Your Health for Science?, ChI. Trib. MAg., Sept. 10, 2000, at 16. 
issues relating to research oversight have become increasingly complex. ${ }^{6}$ In the words of one commentator, "never have so many human clinical trials been underway and offered so much promise for improving human health ... [and] never have the economic and regulatory challenges been as great." Contemporary critics often voice serious concerns about the adequacy of the HHS and FDA regulations as mechanisms to ensure the safety of study participants. $^{8}$

Several commentators have argued that the cure for the regulatory deficit is the revision and enhancement of existing regulations in order to bolster the prospective oversight system. ${ }^{9}$ More specific regulatory guidelines or more resources allocated to IRBs could prevent some mistakes and research abuses. It is apparent, however, that prospective oversight in the form of IRB review, while valuable, cannot be sufficient as the sole mechanism to protect human subjects. This article explores the questions of whether retroactive review in the form of litigation or governmental administrative actions is a workable and useful adjunct to prospective oversight.

Several lawsuits have already named IRBs and IRB members as defendants. ${ }^{10}$ The few isolated cases that have thus far been brought may portend a future fraught with litigation against IRBs. Such litigation poses new challenges for the IRB oversight system. First and foremost is the

6. See id.; see also Kurt Eichenwald \& Gina Kolata, Drug Trials Hide Conflicts for Doctors, N.Y. Times, May 16, 1999, $\S 1$, at 1 . The article attributes the proliferation of drug trials in the 1990 s to managed care and the restrictions it placed on drug prices. Since drug companies were limited in the prices they could charge for each drug, they opted to increase the number of drugs they sold in order to maintain profitability. Thus began the industry's "rush to drug development." Id.

7. Michael J. Malinowski, Institutional Conflicts and Responsibilities in an Age of AcademicIndustry Alliances, 8 WidENER L. SyMP. J. 47, 47 (2001).

8. See Protecting Human Clinical Research Patients: Hearing Before the Subcomm. on Human Resources of the H. Comm. on Gov't Reform \& Oversight, 105th Cong. (1998) [hereinafter Grob, Protecting Human Clinical Research Patients] (statement of George Grob, Deputy Inspector General for Evaluation and Inspections, Department of Health and Human Services), available at 1998 WL 333481; Carl H. Coleman, Rationalizing Risk Assessment in Human Subject Research, 46 ARIZ. L. Rev. 1, 2 (2004) (stating that "[f]ew would deny that our system of protecting human subjects faces an unprecedented crisis").

9. See, e.g., Office of Inspector Gen., Dep't of Health and Human Servs., Institutional REVIEW BoARds: A TIME FOR REFORM iii (1998), available at http:/oig.hhs.gov/oei/reports/ oei-01-97-00193.pdf (last visited Oct. 26, 2005) (finding the current IRB system lacking and suggesting significant reforms rather than abandoning the regulatory system) [hereinafter A TIME FOR REFORM]; Barbara A. Noah, Bioethical Malpractice: Risk and Responsibility in Human Research, 7 J. HEALTH CARE L. \& POL'Y 175, 239 (2004) (stating that "commentators have proposed a variety of regulatory reforms to improve the safety of clinical research" and citing numerous articles).

10. See David B. Resnik, Liability for Institutional Review Boards: From Regulation to Litigation, 25 J. Legal Med. 131, 134-35 (2004). 
concern that, in light of a serious risk of legal challenges, it will become impossible to recruit members to serve on IRBs, particularly since most volunteer their time and are not compensated for their work. ${ }^{11}$ Further apprehension relates to the possibility of increased research costs associated with legal claims and potential over-deterrence, which may cause risk-averse IRBs to be loath to approve protocols or IRB members to hesitate to discuss their concerns openly during IRB deliberations for fear that their statements will come back to haunt them in the litigation context. ${ }^{12}$

In order to address these potential problems, this article recommends that all claims against IRBs be brought before the FDA or HHS's Office for Human Research Protection (OHRP) for mandatory administrative review prior to the commencement of litigation. ${ }^{13}$ Such review, which would parallel Equal Employment Opportunity Commission (EEOC) investigations of employment discrimination cases and some state agency procedures for peer review challenges, ${ }^{14}$ would serve a useful gatekeeping role. It may filter out or deter frivolous actions, avoid subjecting IRB members and human subjects to media exposure in meritless cases, and resolve some claims quickly, privately, and efficiently.

For cases that do cross the threshold from administrative review to court, we recommend that IRB members be given qualified immunity similar to that available for peer reviewers under the Health Care Quality Improvement Act of 1986 (HCQIA). ${ }^{15}$ IRB members should be immune from liability for civil damages so long as they had a good faith belief that the challenged decision protected the welfare of human subjects and so long as they complied with all federal regulatory requirements concerning protocol review. The promise of qualified immunity should allow IRB membership to remain an appealing form of public service and should promote candid debate within the committee that is motivated solely by a desire to achieve responsible decision-making rather than by concerns about potential litigation.

Part I of this article provides an overview of modern-day research abuses and the development of federal research regulations. Part II analyzes the emerging phenomenon of litigation against IRBs, stemming from a changed research landscape in the U.S. Part III explores the history of IRB litigation, and Part IV describes various theories of liability that can be used to sue IRBs.

1. See infra Part V.A.1.

12. See infra Parts V.A.2 and V.A.3.

13. See infra Part VI.A.

14. See infra Part VI.A.

15. 42 U.S.C. $\S \S 11101-11152$ (2000); see infra Part VI.B. 
Part V evaluates policy arguments for and against imposing liability upon IRBs, and Part VI offers specific recommendations to safeguard both the welfare of human subjects and the integrity of the IRB oversight system.

\section{Overview of Twentieth Century Research Abuses and the Development of Research Regulations}

\section{A. Historical Background}

The history of biomedical research is rife with abuses, many of which have gone unpunished. During World War II, Nazi doctors conducted largescale experiments on concentration camp inmates that constituted not only a form of research, but also a mechanism of torture and killing. In some camps, prisoners were infected with yellow fever, smallpox, typhus, cholera, and diphtheria germs that caused hundreds of deaths. ${ }^{16}$ Elsewhere, the Nazis conducted experiments relating to high altitude, malaria, freezing, mustard gas, bone transplantation, sea water, sterilization, and incendiary bombs. ${ }^{17}$ The extent and horrors of the Nazi medical experimentation program were revealed and documented during the Nuremberg Trials after World War II. ${ }^{18}$

In the United States, medical research was conducted for many decades without any formal oversight or monitoring. ${ }^{19}$ Perhaps not surprisingly, in an environment in which regulation was absent, some research subjects were exploited. ${ }^{20}$ In the early 1950s, almost all participants in Phase I studies, the initial and riskiest stage of clinical research, ${ }^{21}$ were prisoners. ${ }^{22}$ In Ohio, for example, inmates were involved in dangerous and painful cancer trials.

16. Allen M. Hornblum, Acres of Skin: Human Experiments at Holmesburg Prison 75

17. Id. at $75-77$.

18. The Nuremberg Trials were opened on November 20, 1945, at the Palace of Justice in Nuremberg, Germany. Fifteen of the twenty-three defendants were found guilty of war crimes and crimes against humanity, and seven of them were sentenced to death. Alexander Mitscherlich \& Fred Mielke, Epilogue: Seven Were Hanged, in The Nazi Doctors And the Nuremberg Code 105 (George J. Annas \& Michael A. Grodin eds., 1992); Bernard Meltzer, "War Crimes": The Nuremberg Trial and the Tribunal for the Former Yugoslavia, 30 Val. U. L. Rev. 895, 896 (1996). See generally Robert J. Lifton, The NAZI Doctors (1986).

19. Harold Y. Vanderpool, Introduction and Overview: Ethics, Historical Law Studies, and the Research Enterprise, in The Ethics of Research Involving Human Subjects: Facing the 21st CENTURY 8 (Harold Y. Vanderpool ed., 1996).

20. $I d$.

21. See id. 21 C.F.R. $\S 312.21$ (a) (2005). Human research studies are often called clinical trials. See id. $\S 312.21$ (a)-(c).

22. Hornblum, supra note 16 , at 43. 
Doctors would implant cancer cells in both of the prisoner's forearms ${ }^{23}$ and, after two weeks, would surgically remove the affected area of one arm, leaving the malignant cells in the other forearm for further observation. ${ }^{24}$ The CIA conducted secret psychological experiments at the Ionia State Hospital in Michigan, for which it recruited at least 142 inmates. $^{25}$ As late as 1969, eighty-five percent of new medications were still tested on prisoners. ${ }^{26}$

In the decades following WWII, research abuses were not limited to the prison population, but also involved other vulnerable subjects. ${ }^{27}$ For example, researchers injected live cancer cells subcutaneously in patients at the Jewish Chronic Disease Hospital in Brooklyn and infected retarded children at the Willowbrook State School on Staten Island with a mild strain of hepatitis. ${ }^{28}$ The experiments were conducted without the knowledge or consent of the participants or their guardians. ${ }^{29}$ In 1966, Dr. Henry Beecher published an article describing twenty-two ethically dubious research projects. ${ }^{30}$

In 1972, the public learned of the notorious Tuskegee syphilis study and became painfully aware of the phenomenon of human subject mistreatment. ${ }^{31}$ The Tuskegee study, focusing on the natural progression of untreated syphilis in African-Americans, involved approximately 400 African-American men and continued from 1932 until the beginning of the 1970s. ${ }^{32}$ Although penicillin, an antibiotic that is a fully effective cure for syphilis, was widely available as early as 1953, the research participants were neither informed of the drug's existence nor given access to it. ${ }^{33}$ The men believed they were

\footnotetext{
23. Id. at 93 .

24. $I d$.

25. Id. at 95 .

26. Kathleen Schroeder, A Recommendation to the FDA Concerning Drug Research on Prisoners, 56 S. CAL. L. REV. 969, 971 (1983).

27. See Henry K. Beecher, Ethics and Clinical Research, 274 New Eng. J. Med. 1354, 1354-60

28. Vanderpool, supra note 19, at 9.

29. $I d$.

30. See generally Beecher, supra note 27 , at $1356-59$.

31. James H. Jones, Bad Blood: The Tuskegee Syphilis Experiment 1 (1993); Colleen M. McCarthy, Note, Experimentation on Prisoners: The Inadequacy of Voluntary Consent, 15 NEw ENG. J. on Crim. \& Civ. Confinement 55, 58 (1989); Vanderpool, supra note 19, at 9. The first report of the study appeared in a July 1972 article by Jean Heller entitled "Syphilis Victims in U.S. Study Went Untreated for 40 Years." Jean Heller, Syphilis Victims in U.S. Study Went Untreated for 40 Years, N.Y. Times, July 26, 1972, at A1.

32. Vanderpool, supra note 19, at 9; see also Mark A. Hall et al., Health Care LaW and Eтнісs 230 (6th ed. 2003).

33. HALL ET AL., supra note 32, at 230; Vanderpool, supra note 19, at 9.
} (1966). 
receiving state of the art care, but they continued to suffer unnecessarily from the debilitating effects of their illness. ${ }^{34}$

Ultimately, the federal government responded to publicity concerning research abuses by establishing oversight regulations. The FDA and the National Institutes of Health $(\mathrm{NIH})$ developed internal policy guidelines in 1966 and 1971, respectively, which, in 1974, evolved into federal regulations. ${ }^{35}$ The National Research Act of $1974^{36}$ created the National Commission for the Protection of Human Subjects in Biomedical and Behavioral Research, which operated for four years, until 1978. ${ }^{37}$ Following the Commission's recommendations, the federal regulations underwent a number of revisions, and they have remained in effect to this day. ${ }^{38}$

\section{B. What Is Regulated?}

The FDA regulates research studies, generally termed "clinical trials," that are designed to develop new drugs, medical devices, and biological products such as vaccines and blood products. ${ }^{39}$ Clinical trials that involve treatments other than drugs and devices, such as surgery or bone marrow transplants, are not within the jurisdiction of the FDA. Many studies that focus on non-FDA regulated therapies are subject to HHS regulation, but only if they are "conducted, supported or otherwise subject to regulation by any federal department or agency." " Institutions engaged in federally funded research are required to provide an assurance that all research at the institution will conform to federal guidelines. ${ }^{41}$ However, research conducted at institutions that do not provide assurances may fall outside the jurisdiction of the federal regulations if it involves no drugs, devices, or biologics and is funded purely by private sources. ${ }^{42}$

34. HALl ET AL., supra note 32 , at 230

35. Vanderpool, supra note 19, at 10.

36. See National Research Service Award Act of 1974, Pub. L. No. 93-348, § 201, 88 Stat. 342; McCarthy, supra note 31, at 58-59.

37. Baruch A. Brody, Ethical Issues in Drug Testing, Approval, and Pricing 103 (1995),

38. Vanderpool, supra note 19 , at 10.

39. See 21 C.F.R. § 50.1 (2005); see also U.S. Food and Drug Administration Home Page, http:// www.fda.gov (last visited Oct. 26, 2005) (describing all items regulated by the FDA).

40. See 45 C.F.R. $\S 46.101$ (a) (2005).

41. Id. $\S 46.103$ (a).

42. See E. Haavi Morreim, Medical Research Litigation and Malpractice Tort Doctrines: Courts on a Learning Curve, 4 Hous. J. Health L. \& Pol'y 1, 62 (2003). 
C. IRBS

Federal regulations mandate that all research that is conducted, supported, or regulated by HHS, the FDA, or another federal agency must be overseen by an IRB ${ }^{43}$ a committee constituted to provide initial approval and periodic monitoring for biomedical research studies. ${ }^{44}$ The IRB's primary role is to safeguard the rights and welfare of human subjects. ${ }^{45}$ For each proposed clinical trial, the IRB reviews the objectives of the research, its procedures, eligibility requirements for participants, the number of subjects to be recruited, and other details. ${ }^{46}$ The IRB also scrutinizes a document known as the "informed consent" form, which is given to all potential enrollees in order to provide them with an extensive explanation of the clinical trial and to obtain their written consent to participate in the study. ${ }^{47}$

The IRB's structure and duties are governed by the HHS and FDA regulations. Each IRB must be comprised of at least five members, including both men and women, who should have diverse cultural and ethnic backgrounds. $^{48}$ At least one member of the IRB should have scientific expertise, while one individual must be a nonscientist. ${ }^{49}$ Furthermore, to promote objectivity, each IRB must have at least one member who is not otherwise affiliated with the research facility and who has no immediate family members affiliated with the entity. ${ }^{50}$ Many IRB members, however, are affiliated with academic research institutions as either full-time faculty, clinical researchers, or administrators. ${ }^{51}$ Academic institutions usually do not pay IRB members for their work or offer them relief from other job duties, so IRB service often is purely voluntary. ${ }^{52}$ Because of their other job

43. 21 C.F.R. $\S 56.103$ (2005); 45 C.F.R. $\S 46.101$ (a) (2005).

44. 21 C.F.R. $\$ 56.102(\mathrm{~g})$.

45. $I d$.

46. 21 C.F.R. $\S 56.111 ; 45$ C.F.R. $\S 46.111$ (discussing criteria for approval of studies).

47. 21 C.F.R. $\S 50.20$ (2005); 45 C.F.R. $\S 46.116$.

48. 21 C.F.R. $\S 56.107(a) ; 45$ C.F.R. $\S 46.107(a)$.

49. 21 C.F.R. $\$ 56.107$ (c); 45 C.F.R. $\$ 46.107($ c).

50. 21 C.F.R. $\S 56.107($ d); 45 C.F.R. $\S 46.107(d)$.

51. According to a now somewhat out-of-date government survey, eighty percent of IRB members in 1995 were affiliated with academic research institutions as full-time faculty $(56 \%)$, clinical and research staff (18\%), and administrators (6\%). James Bell et al., Final Report: Evaluation of NIH Implementation of Section 491 of the Public Health Service Act, Mandating a Program of Protection for Research Subjects 17 (National Institutes of Health Contract No. N01-OD-2-2109, 1998).

52. See Kerry Burke, Note, Loose-Fitting Genes: The Inadequacies in Federal Regulation of Institutional Review Boards, 3 B.U. J. SCI. \& TECH. L. 10, I 38 (1997). But see infra Part V.A.1 (discussing for-profit IRBs in which members are paid for their protocol reviews). 
responsibilities, members can spend only limited time on IRB work, and IRBs generally meet only once or twice a month for a few hours.

Expedited review is allowed for some studies involving no more than minimal risk and for minor changes in already approved protocols. ${ }^{53}$ Otherwise, new protocols and amendments must be reviewed at IRB meetings at which a majority of the members are present, including at least one nonscientist. ${ }^{54}$ The IRB may approve, disapprove, or require modifications to the proposed research activities by majority vote. ${ }^{55}$ It must give investigators written notification of its decisions and monitor each clinical trial throughout its duration. This monitoring, called "continuing review," must be conducted at least annually or may be conducted more frequently, depending on the risks posed by the study. ${ }^{56}$

In assessing a clinical trial, the IRB must evaluate a number of specific criteria. Such criteria include whether: (1) the risks to subjects are minimized; (2) the risks to participants are reasonable in light of expected benefits; and (3) subjects are selected in an equitable manner, and the protocol is sensitive to the particularized problems of research involving vulnerable populations such as children, prisoners, pregnant women, mentally disabled individuals, or economically or educationally deprived persons. ${ }^{57}$ Accordingly, each protocol must receive a thorough individualized assessment.

\section{Contemporary Concerns Prompting Litigation}

The IRB system is subject to explicit federal regulation and has survived several decades of being tested in practice. Why is there now renewed concern regarding research abuses ${ }^{58}$ and a nascent interest in legally challenging IRB decisions? The answer is rooted in contemporary changes to the research environment.

53. 45 C.F.R. $\S 46.110$.

54. 21 C.F.R. $\S 56.108(c) ; 45$ C.F.R. $\S 46.108(b)$.

55. 21 C.F.R. $\S 56.109$ (a); 45 C.F.R. $\S 46.109$ (a).

56. 21 C.F.R. $\S 56.109$ (e)-(f); 45 C.F.R. $\S 46.109$ (d)-(e)

57. 21 C.F.R. $\S 56.111$ (a); 45 C.F.R. § 46.111(a).

58. See supra notes 6-8 and accompanying text. 


\section{A. Dramatically Increased IRB Workloads}

A 1998 report issued by the Office of Inspector General (OIG) of the U.S. Department of Health and Human Services expressed alarm concerning present-day research oversight. ${ }^{59}$ The OIG stated that the enormous workloads that currently burden many IRBs prevent them from performing their review functions adequately. It found that the average local IRB met for two-and-ahalf hours at a time and voted on eighteen initial reviews, nine expedited reviews, forty-three amendments, and twenty-one safety reports during each meeting. ${ }^{60}$ A follow-up OIG report issued in April of 2000 concluded that in the intervening two years, only minimal progress had been made to ease IRB workload pressures. ${ }^{61}$ The number of initial reviews conducted by IRBs grew by an average of forty-two percent from 1993 to 1998, and some IRBs

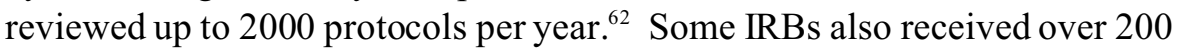
reports per month of adverse events experienced by subjects in the clinical trials they oversaw. ${ }^{63}$ According to another source, on average, the number of protocols reviewed by IRBs has increased from 40 to 300 annually. ${ }^{64}$

Reports from particular institutions illustrate the problem even more dramatically. At Duke University, the IRB reviewed 400 protocols in 1974 compared to at least 2200 in 2001, and at the University of California at San Francisco, the number has skyrocketed from 100 in 1966 to almost 4000 in 1999. ${ }^{65}$ An external review conducted at Johns Hopkins University after the death of a healthy research volunteer disclosed that until June of 2001 a single IRB, meeting once every two weeks, was responsible for the approval of 800 new protocols annually and the continuing monitoring they generated. ${ }^{66}$ The external reviewers emphatically stated: "We view this as grossly inadequate. ${ }^{967}$

59. A Time For REForm, supra note 9, at 6 .

60. Id.

61. 2000 OIG REPORT, supra note 2, at 2-3.

62. Id. at 5. The average local IRB meeting was found to last approximately two-and-a-half hours and to include eighteen initial reviews, nine expedited reviews, forty-three amendments to protocols and twenty-one adverse-event reports. $I d$. at 6 .

63. Id. at 5 .

64. See Anderlik \& Elster, supra note 4, at 223 (citing Human Subject Research Protections: Hearing Before the Subcomm. on Criminal Justice, Drug Policy and Human Resources of the H. Comm. on Government Reform, 106th Cong. (2000) [hereinafter Human Subject Research Protections].

65. $I d$.

66. Robert Steinbrook, Protecting Research Subjects—The Crisis at John Hopkins, 346 NEw ENG. J. Med. 716, 719 (2002).

67. $I d$. 


\section{B. Inadequate Resources}

HHS's Office for Protection from Research Risks (OPRR), now the Office for Human Research Protection (OHRP), expressed concern that IRBs' work is also hampered by deficient expertise and resources. ${ }^{68}$ Some IRB members lack an in-depth understanding of the federal regulations governing biomedical research, and IRBs do not have the space, privacy, and level of staff support necessary to perform their duties adequately ${ }^{69}$ Small IRBs may have only one salaried staff member to coordinate all IRB activities and perform administrative tasks. ${ }^{70}$ Without adequate professional staff support, IRBs may be unable to follow up with investigators to ensure that they have answered all IRB inquiries and complied with instructions for protocol or informed consent changes, nor can they conduct meaningful continuing reviews of ongoing studies. ${ }^{71}$

\section{Multicenter Clinical Trials}

Multicenter clinical trials are now a common phenomenon in the American research landscape. These studies are conducted at multiple research institutions across the country and even around the world. ${ }^{72}$ Local IRBs have only limited control over multicenter protocols for a variety of reasons. ${ }^{73}$ IRBs might meet increased pressure to approve multicenter studies as is because sponsors can remove protocols from institutions whose IRBs demand substantive modifications, and investigators might vocally resist changes requested by a local IRB on the ground that other IRBs have already approved the study without such revisions. ${ }^{74}$

68. See generally Office for Human Research Prots., U.S. Dep't of Health \& Human Servs., OHRPCOMPliance Oversight Activities: Significant Findings and Concerns of Noncompliance (2005) [hereinafter OHRP REPORT], available at $\mathrm{http}: / / \mathrm{www} . h \mathrm{~h}$ s.gov/ohrp/compliance/findings.pdf (last visited Oct. 26, 2005).

69. $I d$.

70. A TIME FOR REFORM, supra note 9, at 5. For recommendations concerning the staffing of IRBs, see Sharona Hoffman, Continued Concern: Human Subject Protection, The Institutional Review Board, and Continuing Review, 68 Tenn. L. Rev. 725, 748-55 (2001).

71. For a discussion of the failures of the continuing review process, see Hoffman, supra note 70, at $735-38$.

72. Anderlik \& Elster, supra note 4, at 223.

73. See Charles R. McCarthy, Challenges to IRBs in the Coming Decades, in The Ethics of Research Involving Human SubJeCts: FaCing the 21 st Century, supra note 19, at 127, 135.

74. Id. 
Problems may also arise with respect to continuing reviews. While local IRBs will have access to information concerning subjects enrolled at their own institution and will be able to interview investigators concerning the progression of particular studies, they may not have comprehensive information about emerging data at other centers. ${ }^{75}$ Even if they receive adverse event reports from other centers, it is possible that local IRBs will be unable to interpret them adequately without detailed information regarding the aggregate number of subjects enrolled at each center and other specifics. ${ }^{76}$ Consequently, a local IRB may not be able to make a fully educated decision regarding whether an ongoing multicenter study should be stopped, altered, or have its informed consent document revised at the local institution. Some commentators have, in fact, suggested the elimination of local IRBs, calling instead for the establishment of regional ethics boards or national advisory panels with specific areas of expertise. ${ }^{77}$

\section{Conflicts of Interest and Professionalism}

Medical professionalism has received increased attention over the past couple of decades in light of dramatic changes in health care financing and delivery. ${ }^{78}$ Although a full exploration of medical professionalism is beyond the scope of this article, several specific concerns are worth considering briefly.

At its best, professionalism functions as a protective measure to counteract a significant power differential between the highly trained professional and the individual using the professional's services. ${ }^{79}$ Professional relationships are thought to be different from other types of

75. $I d$.

76. See Burman et al., supra note 2, at 152-57 (highlighting the problems of local IRB review of multicenter clinical studies).

77. Transcript of Testimony before the President's Councilon Bioethics (Sept. 12,2002) (statement of Ezekiel J. Emanuel, Chief, Ctr. for Clinical Bioethics, Nat'l Insts. of Health), available at http:// www.bioethics.gov/transcripts/sep02/session2.html (last visited Oct. 26, 2005); see also Harold Edgar \& David J. Rothman, The Institutional Review Board and Beyond: Future Challenges to the Ethics of Human Experimentation, 73 MiLBANK Q. 489, 489-90 (1995).

78. See generally Matthew K. Wynia et al., Medical Professionalism in Society, 341 New Eng. J. Med. 1612 (1999).

79. See generally Eliot Freidson, Professionalism Reborn: Theory, Prophecy and Policy (1994). A number of commentators take issue with this positive view of professionalism. See, e.g., Allen E. Buchanan, Is There a Medical Profession in the House?, in Conflicts of Interest in Clinical Practice and Research 105 (Roy G. Spece, Jr. et al. eds., 1996) [hereinafter Conflicts of Inter est]. 
relationships, such as that between a shopkeeper and a client, for example. ${ }^{80}$ They are characterized by the subordination of the professional's personal interests - e.g., money and recognition - to the patient's interests and also by the development of professional ethical standards of care. ${ }^{81}$ This is an ideal, however, and the literature on conflicts of interests in medicine recognizes that the simplistic model of the primacy of patient interests to the exclusion of all else may not be accurate even in the treatment context. ${ }^{82}$ Nonetheless, the treatment context is characterized by a primary reliance on professionalism to safeguard patients with retroactive review of medical decision-making provided only through litigation. ${ }^{83}$ Medical professionals in treatment situations are assumed to make decisions according to ethical guidelines and to put the individual patient's interests above other interests. As a result, most treatment decisions are not subject to oversight before implementation, and they are only challenged retroactively when something goes wrong. This retroactive review through the legal malpractice system provides a mechanism for compensating patients who are harmed. But more importantly, from a professionalism standpoint, it serves as an incentive to encourage adherence to professional standards and to maintain the primacy of the patient's interests in medical decision-making.

The shift from the treatment context to the research context raises novel complexities and challenges the adequacy of professionalism as a protective force. ${ }^{84}$ To a certain extent, the limitations of the professionalism model have always been recognized in the research context, which is regulated via prospective review and approval, rather than through primary reliance on professional ethical standards and potential retroactive review. ${ }^{85}$ One reason

80. Samuel Haber, The Quest for Authority and Honor in the American Professions: 1750-1900, at 8 (1991) (citing Adam Smith's distinction between professionals and other business people who require trust in their relationships with clients).

81. Talcott Parsons, Essays in Sociological Theory 35 (1954); David Ozar, Profession and Professional Ethics, in 4 Encyclopedia of Bioethics 2103 (Warren Thomas Reich ed., 1995).

82. See generally CONFLicts OF INTER EST, supra note 79 (discussing physician conflicts in the treatment arena arising from reimbursement mechanisms, lack of health care resources, multiple patient obligations, multiple job obligations, and personal obligations).

83. Managed care organizations subject some treatment decisions to prior utilization reviews in order to determine their necessity and appropriateness. These are different, however, from IRB reviews, since they are designed primarily to control costs rather than to protect patients. BARRY R. FURROW ET AL., Health Law Cases, Materials and Problems 627 (5th ed. 2004).

84. See generally CONFLICTS OF INTER EST, supra note 79 (discussing researcher conflicts based on funding source (e.g., industry versus government) and job requirements (e.g., tenure and pressures to publish)).

85. Jessica W. Berg et al., Informed Consent: Legal Theory and Clinical Practice 258 (2d ed. 2001). 
the professionalism model fails in the research context is because unlike physicians and patients, investigators and subjects cannot claim to share all or even most of the same goals, although there may be some overlap. ${ }^{86}$ Even if some goals are shared, such as the advancement of knowledge, the weight given to each goal by investigators and subjects is likely to be significantly different. For example, investigators may focus primarily on the success of the research, whereas subjects likely will focus primarily on their own health and only secondarily on promoting scientific knowledge. ${ }^{87}$ The relationships between health professionals and subjects in the research context strain the traditional medical professional model.

The prospective research review system was put in place because of these realities. But the system relies heavily on IRB review as a safeguard, and the IRB members themselves may face a number of conflicts of interest that interfere with their ability to place primary emphasis on subject interests. ${ }^{88}$ Some of these may be individual conflicts, such as those arising out of the IRB members' own research, since decisions made by the committee may have direct or indirect implications for a member's own work. ${ }^{89}$ Moreover, members may be concerned that adverse decisions concerning certain protocols will affect their personal compensation (since grant overhead may provide a salary source) or their promotion and tenure. ${ }^{90}$ An additional concern is the loyalty of IRB members to the investigators proposing the research project. Often, the investigators are colleagues of IRB members, since they are on faculty or staff at the same institution. ${ }^{91}$ IRB members may be loath to alienate their associates by voting against their protocols or by requiring submission of further information and revisions. ${ }^{92}$ There is

86. Id.

87. Sharona Hoffman, The Use of Placebos in Clinical Trials: Responsible Research or Unethical Practice?, 33 Conn. L. Rev. 449, 475, 490-95 (2001). The therapeutic misconception refers to subjects' consistent failure to understand the distinctions between research and treatment and their erroneous belief that studies are designed specifically to provide treatment for their illnesses. Paul S. Appelbaum et al., False Hopes and Best Data: Consent to Research and the Therapeutic Misconception, 17 Hastings Ctr. REP. 20 (1987).

88. Leslie Francis, IRBs and Conflicts of Interest, in CONFLICTS OF INTER EST, supra note 79, at 418.

89. See id. at 423 (suggesting that conflicts can include the adoption of procedures that do not result in greater burdens when the member conducts research).

90. Id. Promotion and tenure depend, in part, on internal evaluation by senior colleagues, whose studies the IRB members review.

91. Id. at 425 .

92. Bernard Lo \& Michelle Groman, NBAC Recommendations on Oversight of Human Subject Research, 32 Seton Hall L. Rev. 493, 504 \& n. 34 (2002)(citing 1 Nat'L Bioethics Advisory Comm'n, Ethical and Policy Issues in Research Involving Human Participants 60 (2001), available at http://www.georgetown.edu/research/nrcbl/nbac/human/overvol1.pdf (last visited Oct. 26, 2005)). 
considerable evidence that IRBs rarely disapprove research, instead allowing investigators to revise protocols multiple times and to convince the committee that they should ultimately be approved. ${ }^{93}$

The bias in favor of approving research may stem not only from individual conflicts of the IRB members, but also from the position of the IRB within the research institution. For example, IRB members may have institutional loyalty and wish to promote research at their facility. ${ }^{94}$ Some commentators assert that increasing commercial sponsorship of research studies further compromises the integrity of IRB review. ${ }^{95}$ The Bayh-Dole Act, passed in 1980, provided incentives for universities to obtain patents on the products of federally funded research. ${ }^{96}$ Research at universities, consequently, can be quite lucrative, leading to well over 3000 patents annually in recent years. ${ }^{97}$ For-profit corporations often pursue public-private partnerships with universities, funding seventy percent of academic institutions' clinical trials for new drugs, rather than using in-house research programs. ${ }^{98}$ Deep-pocket corporate sponsors often dictate the provisions of the protocol, and research institutions know that displeased sponsors can take their funding elsewhere. In congressional testimony, a high-level government official noted that "IRBs feel pressure to accommodate these sponsors who are looking for quick turnaround of their research and for whom time is money." ${ }^{\prime 9}$

93. See Robert Levine, Ethics and Regulation of Clinical Research 333 (2d ed. 1986) (stating that the IRB "nearly never labels a protocol disapproved"); see also John A. Robertson, The Law of Institutional Review Boards, 26 UCLA L. Rev. 484, 547-48 (1979) (citing a National Commission survey finding "that modifications were required in only twenty-five percent of the protocols reviewed, with nearly all of them in the consent form" and concluding "the current system of institutional research review boards, like all self-regulatory systems, will favor the interest of researchers").

94. Robertson, supra note 93, at 547.

95. Anderlik \& Elster, supra note 4, at 223.

96. Bayh-Dole Act, Pub. L. No. 96-517, 94 Stat. 3015 (1980) (codified as amended at 35 U.S.C. $\S \S 200-210(2000))$.

97. AtifI. Azher, Antitrust Regulators and the Biopharmaceutical Industry: Compulsory Licensing Schemes Ignoring Gene Therapy Patients'Needs, 25 U. PA. J. InT'L Econ. L. 383, 390 (2004).

98. Janice M. Mueller, No "Dilettante Affair": Rethinking the Experimental Use Exception to Patent Infringement for Biomedical Research Tools, 76 WASH. L. Rev. 1, 34 (2001); see also Coleman, supra note 8 , at 7 (noting that the majority of contemporary research is supported by pharmaceutical companies).

99. Grob, Protecting Human Clinical Research Patients, supra note 8; see also Lori A. Alvino, Note, Who's Watching the Watchdogs? Responding to the Erosion of Research Ethics by Enforcing Promises, 103 Colum. L. Rev. 893, 906-07 (2003) (noting criticism that "researchers are 'for sale,' that their engagement in clinical research can be bought or bartered, and that the outcome of research is thus biased by academic-industrial alliances - whether those alliances are personal to the researcher or institutional"). 
All of this is not to say that IRB members are acting against subject interests or that professionalism cannot operate in this context. However, professionalism is not a sufficiently effective safeguard in the current IRB system. If professionalism is to serve an important role in providing safeguards for subjects, then a change is needed to promote the role of professionalism in the IRB review context. Although the prospective review system may succeed in mitigating conflicts arising from the lack of traditional professional obligations between researchers and subjects by providing an external check on investigator decision-making, it does little to mitigate potential conflicts of the IRB members themselves. One response to this failure has been to suggest that more laypersons take part in the research approval process, as they may bring the lay subject's perspective to discussions and thus ensure the priority of subject interests. But, simply increasing the use of laypersons in the prospective review system will not solve the problem. ${ }^{100}$ In fact, the addition of lay IRB members who are, by definition, not medical professionals will decrease the likelihood that professionalism will function as a safeguard against conflicts of interest.

While the approval process could certainly be enhanced through regulatory and procedural changes, this article suggests that a carefully constructed system of retrospective review can constitute an additional important improvement because it will promote professionalism and make IRB members accountable for the consequences of their actions. As recent years have demonstrated, litigation against IRBs appears to be an inevitable phenomenon. With appropriate safeguards, however, litigation could bolster rather than undermine the oversight system. We recommend a framework in which IRB decisions can be challenged through administrative oversight with limited subsequent litigation. We explore the implications of this proposal in Part VI.

100. Laypersons do not have the capacity to evaluate whether professionals are providing adequate services, and thus professionals must develop and maintain ethical guidelines. These guidelines serve as a mechanism of professional self-regulation - a part of the professionalism model of protections. By some accounts, the initial development of professional ethical guidelines, "professionalization" itself, came about in response to laypersons' inability to evaluate professional competence. See, e.g., Paul Starr, The Social Transformation of American Medicine (1982). 


\section{History of Litigation Against IRBs}

Traditionally, IRBs have rarely been named in lawsuits. Several reasons might explain their relative insusceptibility to suit. First, some plaintiffs' lawyers may not be aware of the IRB's oversight function, since the IRB is not as visible an actor as the trial sponsor, doctors, and hospital involved in administering the protocol. This invisibility, however, is likely changing in light of extensive media coverage of high-profile cases of alleged research abuse, such as the Jesse Gelsinger death. ${ }^{101}$

Another reason that IRB litigation is rare is because some lawyers may believe that joining an IRB will add little value to the suit. Many IRBs are likely covered by their research institution's malpractice insurance, ${ }^{102}$ and thus they do not provide a new financial resource beyond other parties that are already named. Individual IRB members are unlikely to have personal malpractice insurance for their IRB work and, consequently, will not constitute deep pockets.

Also, lawyers may believe that it is strategically better to name only a few defendants in order to avoid confusing or distracting the jury. They might therefore decline to name the IRB, because its involvement seems more remote than that of other parties such as the sponsor, investigators, and hospital. ${ }^{103}$ Furthermore, attorneys might hope that if IRB members are not joined as defendants, they will offer cooperation in testifying against the prime targets of the lawsuit. ${ }^{104}$

Nevertheless, IRBs are vulnerable to suit. The first case in which an IRB was named as a defendant dates back to 1973. The case of Nielson v. Regents

101. Jesse Gelsinger was an eighteen-year-old man with a rare metabolic disease who died in 1999 while undergoing experimental genetic therapy administered in a clinical trial at the University of Pennsylvania. See Rick Weiss \& Deborah Nelson, Teen Dies Undergoing Experimental Gene Therapy, WASH. Post, Sept. 29, 1999, at A1.

102. Resnik, supra note 10, at 179 (stating that "[m]any IRB members probably have some form of indemnification from their host institutions or employers," often in the form of a university insurance policy); see also Robert J. Amdur \& Elizabeth A. Bankert, Institutional Review Board MANAGEMENT AND FunCtion 343 (2002) (urging IRB members to ascertain that they are covered by insurance); Anderlik \& Elster, supra note 4, at 226 (noting that the extent to which institutions currently offer IRB members insurance or indemnification is unclear).

103. For example, in the well-known case of Jesse Gelsinger, who died while participating in a gene therapy trial at the University of Pennsylvania, the IRB was not named as a defendant. See Complaint at - 45, Gelsinger v. Trs. of the Univ. of Pennsylvania (Phila. County Ct. Com. P1. 2000), available at http:// www.sskrplaw.com/links/healthcare2.html (last visited Oct. 26, 2005).

104. Richard S. Saver, Medical Research Oversight from the Corporate Governance Perspective: Comparing Institutional Review Boards and Corporate Boards, 46 WM. \& MARY L. REV. 619, 675-76 (2004). 
of the University of California ${ }^{105}$ involved claims of defective informed consent and coercion. ${ }^{106}$ Families were given $\$ 300$ for enrolling their children, and the parents were all students or junior staff members at the university's medical facility. There is no record of a resolution on the merits of the case, which apparently settled. ${ }^{107}$ A year later, in Bailey v. Mandel, ${ }^{108}$ jail inmates sued IRB members for injuries they allegedly suffered as a result of medical research to which they did not consent. ${ }^{109}$ This case also did not generate a reported opinion, and its outcome is unclear. ${ }^{10}$

For several decades thereafter, no high-profile cases addressed the responsibilities of IRBs. ${ }^{111}$ This trend changed at the turn of the twenty-first century with two lawsuits that garnered significant public attention. The first is Grimes v. Kennedy Krieger Institute, Inc. ${ }^{112}$ The case involved researchers at a Johns Hopkins University affiliate who designed a study to determine the

105. Civil No. 655-049 (S.F. Super. Ct., filed Sept. 11, 1973).

106. Roger W. Reinsch, Potential Legal Liability of IRBs - A Legal Perspective, in NIH READINGS on the Protection of Human Subjectsin Behavioral and Social Science Research 120, 128 (Joan E. Sieber ed., 1984). Although the federal regulations were not codified until 1974, the FDA and NIH developed internal policy guidelines in 1966 and 1971. These were converted into the federal guidelines by the Department of Health, Education, and Welfare (HEW) - HHS's predecessor —in 1974, but research oversight activity began several years prior to that date. See supra note 35 and accompanying text. The study at issue in the Nielson case was funded by a grant from HEW and thus subject to its guidelines, and the oversight committee was called the Committee on Human Experimentation, rather than an IRB. Reinsch, supra, at 128.

107. Reinsch, supra note 106, at 129.

108. No. 74-110 (D. Md. 1974). See a description of this case in Robertson, supra note 93, at 533 n. 245 .

109. Robert J. Katerberg, Institutional Review Boards, Research on Children, and Informed Consent of Parents: Walking the Tightrope Between Encouraging Vital Experimentation and Protecting Subjects' Rights, 24 J.C. \& U.L. 545, 574 n.156 (1998).

110. $I d$.

111. A few cases nevertheless involved IRBs. Mason v. Institutional Review Bd. for Human Research, No. 89-3856 \& No. 89-2853, 1992 U.S. App. LEXIS 441 (4th Cir. Jan. 16, 1992), was a suit to enjoin an IRB from suspending research through which the plaintiffs were receiving experimental immune deficiency treatments. The district court granted a preliminary injunction that was dissolved by the appellate court, and the case was ultimately voluntarily dismissed. In Halikas v. University of Minn., 856 F. Supp. 1331 (D. Minn. 1994), a doctor sued the university and its IRB because they had issued a press release disclosing that the IRB would investigate one of the physician's research studies. The court denied the plaintiff's motion for a preliminary injunction and dismissed his claim for damages. In Marinoff v. City College of N.Y., 63 F. App'x 530, 530 (2d Cir. 2003), a physician sued several parties, including the chair of the college's IRB, for a violation of his First Amendment rights resulting from their requirement that he "cease all philosophical counseling activities on the CCNY campus." The appellate court vacated the district court's grant of the defendants' motion to dismiss and remanded the case. Id. at 531-32. A few plaintiffs have also instituted actions seeking disclosure of IRB doc uments to be used in cases against other parties. See infra note 214.

112. 782 A.2d 807 (Md. 2001). 
efficacy of different degrees of lead paint abatement. ${ }^{113}$ Investigators encouraged landlords to rent apartments with lead dust to low-income families with children and periodically took blood samples to measure the lead level in the children's blood. ${ }^{114}$ The informed consent document, approved by the IRB, failed to provide a thorough and lucid explanation of the anticipated risk that lead would accumulate in the children's blood. ${ }^{115}$ In August of 2001, the Maryland Court of Appeals issued an opinion that was harshly critical of the clinical trial. It found that the plaintiffs had stated valid causes of action and reversed the lower court's granting of summary judgment to the defendants. ${ }^{116}$ Although the IRB was not named as a defendant, it was explicitly rebuked by the court with a statement that it had "abdicated... [its] responsibility, instead suggesting to the researchers a way to miscast the characteristics of the study." 117

The second case is Robertson $v . M c G e e,{ }^{118}$ the only case in which IRB members have ever been identified and named individually as defendants in a lawsuit. The case evolved from a melanoma cancer vaccine study at the University of Oklahoma Health Sciences Center in Tulsa. ${ }^{119}$ Eighteen plaintiffs alleged 122 causes of action against twenty-two defendants, including twelve IRB members, claiming injuries resulting from the defendants' failure to comply with federal regulations governing human subject research. ${ }^{120}$ Upon investigation, OHRP confirmed several violations, finding that the IRB's chair approved retroactive changes to the protocol without bringing them to a vote before the full board, that continuing review was inadequate, and that the board made decisions about the protocol without adequate information. ${ }^{121}$ Nevertheless, in January of 2002, a district court in Oklahoma dismissed the case for lack of subject matter jurisdiction, finding

113. Id. at 812 .

114. $I d$.

115. Id. at 813 .

116. Id. at 858 .

117. Id. at 813. For an analysis of the Kennedy Krieger Institute decision, see Diane E. Hoffmann \& Karen H. Rothenberg, Whose Duty Is It Anyway?: The Kennedy Krieger Opinion and Its Implications for Public Health Research, 6 J. Health Care L. \& Pol'y 109 (2002).

118. No. 01-CV-60-C, 2002 U.S. Dist. LEXIS 4072 (N.D. Okla. Jan. 28, 2002).

119. Id. at *4.

120. Id. at *3, *6; Complaint at 223 , Robertson v. McGee, 2002 U.S. Dist. LEXIS 4072 (N.D. Okla. Jan. 28, 2002) (No. 01-CV-60-C) [hereinafter Robertson Complaint], available at http:// www.sskrplaw.com/gene/robertson/complaint-new.html (last visited Oct. 26, 2005).

121. Daniel J. Powell, Comment, Using the False Claims Act as a Basis for Institutional Review Board Liability, 69 U. CHI. L. Rev. 1399, 1403-04 (2002). 
that the federal regulations create no private cause of action. ${ }^{122}$ Consequently, there was no federal question in the case upon which federal court jurisdiction could be based.

Since 2001, Alan Milstein, the lead attorney in the Robertson case, has filed a number of other cases listing IRBs as defendants. ${ }^{123}$ In two such cases, he named numerous "John Doe" IRB members because he could not specifically identify them, and in two others, he named the IRB as a collective defendant. ${ }^{124}$

\section{Potential Causes of Action Against IRBs}

The twenty-first century IRB faces significant hardship in attempting to execute its duties competently. It is possible that the oversight system could be improved through revision of the regulations or the investment of additional resources in the IRB system. But even changes in the prospective review system will not stop lawsuits. IRBs might be sued in two ways: the board members could be sued individually, or the IRB might be sued as an entity. Rather than view such litigation as a problem to be avoided at all costs, we consider whether it might actually bolster the oversight system. Because they may provide powerful incentives for diligent oversight work, lawsuits, if appropriately constrained, could be an important component of a system that provides comprehensive protection to human subjects. We will discuss proposed limitations on litigation in Part VI. This section identifies a variety of legal theories that could be used as a basis for IRB lawsuits. None of these theories will be easy for plaintiffs to prove, and many are quite weak when applied to the IRB context. Nevertheless, it is likely that some or all will be pursued by plaintiffs' attorneys hoping for quick settlements if not for the establishment of important precedent and large jury verdicts.

122. Robertson, 2002 U.S. Dist. LEXIS 4072 , at $* 10-13$.

123. Milstein lists the complaints on his website. See Clinical Trials Litigation, http:// www.sskrplaw.com/gene (last visited Oct. 26, 2005); see also Resnik, supra note 10, at 134-35.

124. See, e.g., Complaint at 7 , Guckin v. Nagle, No. 001425 (Phila. County Ct. Com. Pl. June 2002) (listing 12 John Does), available at http://www.sskrplaw.com/gene/guckin.html (last visited Oct. 26, 2005); Complaint at 10, Wade v. Ore. Health and Sci. Univ., No. 02-CV-877-KI (D. Ore. Aug. 2002) (listing 12 John Does), available at http://www.sskrplaw.com/gene/cordy.html (last visited Oct. 26, 2005); Complaint at 9 , Scheer v. Burke, No. 000375 (Phila. County Ct. Com. Pl. July 2003) (listing the IRB's chairman as a defendant), available at http://www.sskrplaw.com/gene/scheer.pdf(last visited Oct. 26, 2005); Complaint at 4, Hamlet v. Genentech, Inc., No. 03 CVS 1161 (Orange County, NC, Gen. Ct. of Justice, Super. Ct. Div. July 2003) (naming an independent, for-profit IRB, Western Institutional Review Board, Inc., as a defendant), available at http://www.sskrplaw.com/gene/hamletcomplaint.pdf (last visited Oct. 26, 2005). 


\section{A. The Tort of Negligence}

An obvious choice for plaintiffs would be the tort theory of negligence. ${ }^{125}$ Human subjects could allege either that they were injured by the IRB's negligent initial approval of the protocol or by negligent continuing reviews. An IRB could be found liable if it approved or allowed the continuation of a protocol that a reasonable IRB would have declined under the same circumstances. ${ }^{126}$ The elements of a negligence claim are duty, breach of the applicable standard of care, loss or injury, and causation. ${ }^{127}$

\section{Duty}

The question of whether an IRB has a duty of care towards injured human subjects is a complicated one. Duty is defined as "an obligation, to which the law will give recognition and effect, to conform to a particular standard of conduct toward another." 28 One well-known decision described the duty of care as being dependent upon the foreseeability of harm to the plaintiff, the degree of certainty that the plaintiff suffered the injury, the closeness of the connection between the defendant's conduct and the injury suffered, the moral blame attached to the defendant's conduct, the policy of preventing future harm, the extent of the burden to the defendant and the consequences to the community of imposing a duty to exercise care with resulting liability for breach, and the availability, cost and prevalence of insurance for the risk involved. ${ }^{129}$

Furthermore, courts have held that two of the primary factors that determine whether a duty exists are the nature of the harm likely to be suffered if due care is not exercised and the relationship between the relevant parties. ${ }^{130}$ A special relationship may be established by statute or regulation, by contract, or by implication from the interactions among the parties. ${ }^{131}$

125. For a comprehensive discussion of how negligence theory would apply to lawsuits against IRBs, see generally Resnik, supra note 10, at 140-72.

126. Alvino, supra note 99, at 912.

127. Prosser and Keeton on The Law of Torts 164-68 (W. Page Keeton et al. eds., 5th ed. 1984) [hereinafter Prosser \& KEETON].

128. Id. at 356 .

129. Tarasoff v. Regents of Univ. of Cal., 551 P.2d 334, 342 (Cal. 1976).

130. Grimes v. Kennedy Krieger Inst., Inc., 782 A.2d 807, 842 (Md. 2001).

131. Id. 
The Kennedy Krieger Institute court found that a special relationship existed between the subjects and the researchers in the clinical trial setting. This relationship arises from the informed consent document and/or the regulations governing biomedical research. ${ }^{132}$ Because the IRB was not named as a defendant in the case, the court did not specifically rule on whether a special relationship existed between the subjects and the IRB.

It is unlikely that the informed consent document establishes a duty of care on the part of the IRB because it is signed only by subjects and investigators and, at most, could be said to constitute a contract between those parties. ${ }^{133}$ Furthermore, some may argue that IRBs do not come in direct contact with subjects and that they are too far removed from them to have a special relationship in the tort context. ${ }^{134}$ Nevertheless, a future court might find that the federal regulations create an IRB duty of care since IRBs are charged with responsibility for protecting "the rights and welfare of the human subjects," 135 and harm is arguably a foreseeable result of an IRB evading its oversight obligations. ${ }^{136}$

\section{Standard of Care}

The second element of the tort of negligence is breach of the standard of care, but determining the standard of care for an IRB is likely to be a formidable task. Arguably, the federal regulations supply this standard by delineating the various criteria that the IRB must assess during its deliberations. ${ }^{137}$ Nevertheless, the regulatory guidance leaves many gaps and unanswered questions. For example, what deliberative process should an IRB use in assessing each protocol? ${ }^{138}$ Must each member read every protocol or is it sufficient to assign protocols to primary reviewers who in turn present the studies to the group? If none of the IRB members is a specialist in the area to

132. Id. at 858

133. See id. at 843 (holding that the consent form created a bilateral contract between the Kennedy Krieger Institute and the research subjects).

134. See Anderlik \& Elster, supra note 4, at 224.

135. 21 C.F.R. $\$ 56.102(\mathrm{~g})(2005)$

136. See Tarasoff v. Regents of the Univ. of Cal., 551 P.2d 334, 342 (Cal. 1976) (describing the factors to be considered by courts); see also Noah supra note 9, at 209-10 (discussing the possibility that IRBs will be found to have a duty of care towards subjects).

137. 21 C.F.R. § 56.111(a); 45 C.F.R. § 46.111(a) (2005) (listing seven criteria that must be scrutinized by the IRB for purposes of approving protocols).

138. See Coleman, supra note 8 , at 13 (explaining that the "regulations do not specify any particular method IRBs must use to carry out their risk assessment responsibilities" and discussing the procedures that are typically followed by many IRBs). 
be studied in a particular protocol (e.g., breast cancer or psychiatric disorders), must the IRB take extra precautions, such as asking the investigator to join the meeting and explain her protocol, or may members rely on their general knowledge? The regulations merely state that for IRBs regularly reviewing a specific type of research involving a vulnerable population, "consideration shall be given to the inclusion of one or more individuals who are knowledgeable about and experienced in working with" the specific subject group. ${ }^{139}$ Moreover, although IRBs have discretion to "invite individuals with competence in special areas to assist in the review[,] ... [t]hese individuals may not vote." ${ }^{40}$ Even if the initial review is adequate, what constitutes an adequate continuing review? ${ }^{141}$ The regulations provide little help for answering these questions. In a particular case, consequently, it might be extremely difficult to prove that the IRB deviated from a known standard of care. $^{142}$

Another reality that obfuscates the standard of care issue is the presence of a diverse group of members with different areas of expertise. ${ }^{143}$ Should individuals with specialized expertise concerning the condition being studied be held to a standard of care that is different from the standard applied to other IRB members? Would the standard be defined in terms of a reasonable layperson or would the standard be defined in professional terms and need to be established through expert witness testimony? If the latter, what constitutes a professional IRB standard of care and who could testify about it? Furthermore, at issue is not the standard of provision of care that most health care professions have developed, but a standard of review and approval of research. Such a standard has not been delineated by medical professional organizations and thus constitutes novel territory. ${ }^{144}$

In addition, IRBs must include at least one nonscientist. ${ }^{145}$ As mentioned above, some have recently called for a significant increase in the number of laypersons serving on IRBs in order to combat the problem of conflicts of interest and to better represent the beliefs and perceptions of human

139. 45 C.F.R. $\S 46.107$ (a) (2005).

140. Id. $\S 46.107$ (f).

141. See Hoffman, supra note 70 , at 733.

142. See Resnik, supra note 10, at 150 (discussing disagreements about the interpretation of the federal regulations and noting that, in light of their ambiguity, the defendant could always argue "that they do not apply to the challenged conduct").

143. Linda M. Bordas, Note, Tort Liability of Institutional Review Boards, 87 W. VA. L. Rev. 137, 148-49 (1984).

144. See supra Part II.D (discussing professionalism).

145. 21 C.F.R. $\S 56.107$ (c) (2005); 45 C.F.R. $\S 46.107$ (c). 
subjects. ${ }^{146}$ The National Bioethics Advisory Commission, for example, recommended that twenty-five percent of IRB members should be unaffiliated with the research institution, have nonscientific expertise, and represent study participants. ${ }^{147}$

To what standard of care should a layperson with no formal medical education be held? Surely, it should be less stringent than the standard for medical professionals, but how exactly can it be delineated? Furthermore, the average American has approximately an eighth grade reading comprehension level. ${ }^{148}$ If some IRB members are truly to represent the typical study participant, perhaps they too should have a limited education. Such members would make a valuable contribution by listening to the discussion, reading the informed consent document, and pointing out what concepts and written language might be inaccessible to the average study enrollee. Should an entirely different standard of care apply to individuals with no advanced education? Determining the standard of care in negligence cases could, therefore, be an infinitely complicated task.

\section{Loss or Injury}

In some cases, proving harm will not be difficult if subjects suffered physical or mental injury or death that can be clearly linked to the experimental treatment they received. Many trials, however, involve severely ill patients, some of whom turn to clinical trials as a last resort hoping to receive cutting-edge therapy that might cure their otherwise hopelessly advanced conditions. Such patients may have suffered deterioration or death even if they had continued receiving standard therapy, so it will be difficult to prove that the IRB's alleged action or inaction caused them any actual harm. ${ }^{149}$

In addition, some plaintiffs may not suffer diagnosable injuries but might still feel that they have been wronged as participants in a study. Such plaintiffs might allege "dignitary harms" resulting from coercive recruitment

146. Lo \& Groman, supra note 92, at 504-07 (discussing NBAC recommendations to increase the number of community representatives serving on IRBs).

147. National Bioethics Advisory Commission, supra note 92, at 102.

148. See Terry C. Davis et al., Reading Ability of Parents Compared with Reading Level of Pediatric Patient Education Materials, 93 Pediatrics 460, 461-62 (1994); Stuart A. Grossman et al., Are Informed Consent Forms That Describe Clinical Oncology Research Protocols Readable by Most Patients and Their Families?, 12 J. Clinical Oncology 2211, 2212 (1994).

149. See Saver, supra note 104, at 670. 
procedures or flawed informed consent processes. ${ }^{150}$ Several scholars have urged that severe inadequacies in informed consent be recognized as dignitary torts. ${ }^{151}$

At least one court has found damages for dignitary injuries to be appropriate in a case in which a doctor did not use a surgical method that the patient had requested and had been promised. ${ }^{152}$ Arguably, it is even more sensible to rely on a dignitary harms theory in the research context, when patients are recruited to undergo procedures to which they otherwise would not be exposed. ${ }^{153}$ Dignitary harm claims could be based in part on international ethics doctrines, such as the Nuremberg Code ${ }^{154}$ and the Declaration of Helsinki, ${ }^{155}$ which provide research guidance. Thus far, however, only two courts have been receptive in dicta to the idea that international doctrines could serve as a basis for recovery in U.S. cases. ${ }^{156}$

150. Morreim, supra note 42, at 78-85 (discussing the theory of dignitary injuries); Peter Mostow, "Like Building on Top of Auschwitz": On the Symbolic Meaning of Using Data from the Nazi Experiments, and on Non-Use as a Form of Memorial, 10 J.L. \& Religion 403, 422 (1994) (listing "coercion, deception or lack of informed consent" as forms of dignitary harms associated with research); Richard R. Sharp \& Morris W. Foster, An Analysis of Research Guidelines on the Collection and Use of Human Biological Materials from American Indian and Alaskan Native Communities, 42 JURIMETRICS J. 165,171 (2002) (explaining that "[d]ignitary harms involve violations of the right to determine how one's body is used by others" and "lie[] in the loss of control itself, independent of other harms").

151. See Morreim, supra note 42 , at 79 (citing several commentators who have addressed the issue).

152. See Lugenbuhl v. Dowling, 701 So. $2 d$ 447, $455-56$ (La. 1997) (stating that "[i]n this type of case, damages for deprivation of self-determination, insult to personal integrity, invasion of privacy, anxiety, worry and mental distress are actual and compensatory").

153. Morreim, supra note 42, at 79.

154. Nuremberg Code (1947), available at http://www.ushmm.org/research/doctors/ Nuremberg Code.htm (last visited Oct. 26, 2005).

155. World Medical Association, Declaration of Helsinki (2004), available at http://www.wma.net/ e/ethicsunit/helsinki.htm (last visited Oct. 26, 2005).

156. See Grimes v. Kennedy Krieger Inst., Inc., 782 A.2d 807, 835 (Md. 2001) (stating that although no U.S. court has ever awarded damages to an aggrieved research subject based on the Nuremberg Code, the Code applies internationally, including in the U.S.); In re Cincinnati Radiation Litig., 874 F. Supp. 796, 821 (S.D. Ohio 1995) ("The Nuremberg Code is part of the law of humanity. It may beapplied in both civil and criminal cases by the federal courts in the United States.”). 
Most courts reject the notion explicitly. ${ }^{157}$ Even if a jurisdiction allowed such a claim, the recovery amount may be insignificant.

Finally, some commentators suggest a loss of chance theory of harm. ${ }^{158}$ Such harm would stem from an inequitable selection of research participants and the unjustifiable exclusion of potential subjects or subject populations, such as pregnant women. ${ }^{159}$ A patient who wished to receive experimental treatment in the research setting and who believes that she was wrongfully denied enrollment might sue, claiming a lost opportunity for recovery, improvement in health status, or participation in the endeavor of scientific advancement. ${ }^{160}$ A loss of chance theory might also be used by a subject who claims he or she would have participated in a different study had the IRB not improperly approved the protocol in question. Overall, however, loss of chance claims are not likely to constitute a strong basis for lawsuits against IRBs.

\section{Causation}

Causation may also be difficult to prove in a lawsuit against an IRB. As stated above, if the study enrolls critically ill patients, it may not be at all obvious that they fared worse as subjects than they would have absent the challenged research intervention. It will always be arguable that the patient's deterioration is attributable to the natural course of her disease rather than to any action or inaction associated with the clinical trial.

Even if the injury can be associated with the clinical trial, plaintiffs will face obstacles in placing the blame on the IRB. Because the IRB has no

157. Morreim, supra note 42, at 82-83; Robertson v. McGee, No. 01-CV-60-C, 2002 U.S. Dist. LEXIS 4072, at *9-10.

This court agrees with other jurisdictions which have found that there is no private right of action for an alleged violation of international law for the protection of human research subjects under the Declaration of Helsinki and the Nuremberg Code. . . . Moreover, the standard in the United States for conducting research on human subjects is contained in the Code of Federal Regulations and, thus, there is no need for the courts to resort to international law to impute a standard.

Id.

158. Vanessa Merton, The Exclusion of Pregnant, Pregnable, and Once-Pregnable People (a.k.a. Women) from Biomedical Research, 19 AM. J.L. \& MED. 369, 427-28 (1993); AMDUR \& BANKERT, supra note 102 , at 342 (identifying individuals who are excluded from clinical trials as potential plaintiffs).

159. Merton, supra note 158, at 427-28. Pregnant women are often excluded even from relatively benign clinical trials for fear that the experimental treatment will have unpredictable adverse consequences for the fetus. Id. at 381 .

160. Id. 
immediate contact with subjects, its contribution to the injury might seem tenuous at best. It will be far easier to prove negligence on the part of physicians and hospital staff who had a direct role in administering treatment.

Finally, if individual IRB members are sued, it might be nearly impossible to prove how each specifically contributed to the injury. ${ }^{161}$ The chair of the IRB and the primary reviewer of the protocol at issue could logically be held responsible for oversight failures. However, other members might make convincing arguments that deflect blame away from them, and the jury might have to engage in mental acrobatics in order to assign various percentages of responsibility to each individual. ${ }^{162}$ Moreover, in some cases there may be no identifiable failure on the part of any one individual, even though the end determination by the group is flawed. ${ }^{163}$ IRBs work as a group, and there is an extensive literature on the problems that arise from group decisionmaking. ${ }^{164}$ In particular, "groupthink" can result in individuals unwittingly choosing unethical behavior due to influences of the organizational culture. ${ }^{165}$ There is evidence that "[d]uring groupthink small groups develop shared illusions and related norms that interfere with critical thinking and reality testing." ${ }^{166}$ It may be that there is no specific negligence on the part of any one individual, but the final decision is problematic. Because of this, typical tort doctrines like joint and several liability - which is designed to allocate responsibility among multiple tortfeasors - can be extremely difficult to apply.

\section{B. The Torts of Invasion of Privacy and Breach of Confidentiality}

Negligence is not the only theory that plaintiffs might use to sue IRBs. If the IRB mishandles private information concerning particular subjects in the course of assessing adverse events or conducting continuing reviews, the plaintiffs might turn to the common law tort cause of action for invasion of

161. See Resnik, supra note 10, at 165.

162. Id. at 166-67.

163. Janet Fleetwood, Conflicts of Interest in Clinical Research: Advocating for Patient-Subjects, 8 Widener L. Symp. J. 105, 110-11 (2001) (“Another problem plaguing IRBs is 'groupthink'-a phenomena in which one or more members of a group dominate the discussion, leading the group to premature closure by reaching a decision collectively which few might reach if each had relied upon his/her own critical judgment.").

164. See, e.g., IR Ving L. Janis, Victims of Groupthink 2-9 (1972)(describing groupthink); Cheryl Posner-Weber, Update on Groupthink, 18 Small Group Behav. 118 (1987); Cass R. Sunstein, Deliberative Trouble? Why Groups Go to Extremes, 110 YALE L.J. 71 (2000).

165. Ronald R. Sims, Linking Groupthink to Unethical Behavior in Organizations, 11 J. Bus. Eтнics 651 passim (1992).

166. Id. at 653 . 
privacy. ${ }^{167}$ This is especially likely if, without the subject's consent, research information falls into the hands of third parties such as insurers or employers who might use it for purposes of discrimination. Under the common law, the right to privacy can be invaded by "unreasonable publicity given to the other's private life." 168

The tort of disclosure of private facts consists of four elements: (a) public disclosure; (b) of a private fact; (c) that would be objectionable and offensive to a reasonable person; and (d) that is not of legitimate public concern. ${ }^{169}$ In the words of the Restatement (Second) of Torts, "[e]very individual has some phases of his life and his activities and some facts about himself that he does not expose to the public eye[,] . . . [including] many unpleasant or disgraceful or humiliating illnesses[.]"170

In the alternative, plaintiffs could utilize the tort theory of breach of confidentiality. ${ }^{171}$ Courts have based the patient's right of confidentiality upon a variety of sources, including privilege statutes protecting physicianpatient communications, licensing statutes prohibiting the disclosure of patient information without authorization, and medical ethics principles articulated in the Hippocratic Oath and other sources. ${ }^{172}$ In Horne v. Patton, ${ }^{173}$ for example, the court ruled for the plaintiff, finding that his physician breached his duty of confidentiality by disclosing medical information to the plaintiff's employer. The court ruled that a doctor has a duty not to disclose patient information obtained in the course of treatment and that a private cause of action exists in cases where the duty is breached. ${ }^{174}$ An action for breach of confidentiality can be maintained regardless of the degree to which the information has been publicly distributed or the degree of its offensiveness,

167. See Restatement (Second) of Torts $\S 652 A$ (1977).

168. See id.

169. See Diaz v. Oakland Trib., Inc., 188 Cal. Rptr. 762, 767-68 (Cal. Ct. App. 1983) (noting that the jury found the defendant liable for publicizing the fact that the plaintiff had gender corrective surgery, and the award was overturned based on erroneous jury instructions). There are three other kinds of invasion of privacy torts, none of which are likely to be relevant to IRBs - intrusion on seclusion, appropriation of name/likeness, and placing someone in a false light. See Restatement (Second) of Torts § 652A (1977).

170. Restatement (Second) of Torts $\S 652 \mathrm{D} \mathrm{cmt}$. b (1977).

171. See Peter A. Winn, Confidentiality in Cyberspace: The HIPAA Privacy Rules and the Common Law, 33 Rutgers L.J. 617, 652-58 (2002) (discussing the common law tort theory of breach of confidentiality and its implications).

172. Id. at 654-55.

173. 287 So. 2d 824 (Ala. 1973).

174. Id. at 829-30. 
and there is no requirement to prove the intent of the perpetrator. ${ }^{175}$ Thus, in some cases, the breach of confidentiality concept might be a wiser choice for aggrieved parties than invasion of privacy.

No plaintiff has tested these theories in a suit against an IRB, and it is unclear whether courts will accept them outside the context of a direct doctorpatient relationship. There have been recent examples, however, of inadvertent disclosures of information that highlight concerns about privacy and confidentiality. In one instance, the Veterans Administration sold a number of old computers with private medical information (including names, HIV status, and mental health information) to the public, and in another case a woman purchased a computer that had a list of 2,000 patients still on the hard drive. ${ }^{176}$ With the growing volume of research data being processed, it is not unimaginable that a computer glitch or human error might lead to such a mishap in the research context.

\section{The Tort of Breach of Fiduciary Duty}

A separate tort for which plaintiffs may be awarded damages is breach of fiduciary duty, which arises from a fiduciary's obligation to promote the interests of his beneficiaries rather than his own interests. ${ }^{177}$ A key aspect of fiduciaries is that they are entrusted with the power and discretion to make certain decisions that cannot be monitored or limited ahead of time by the entrustor. ${ }^{178}$ As a result, the law imposes certain obligations on the fiduciary. Fiduciary duties consist of a duty of care, requiring diligence of fiduciaries who are making decisions on behalf of beneficiaries, and a duty of loyalty, obligating fiduciaries to promote the beneficiaries' best interests instead of their own. ${ }^{179}$ Fiduciary principles have been applied to a diverse variety of relationships, including trustee-beneficiary, guardian-ward, insurance company-insured, priest-penitent, and bank-customer. ${ }^{180}$

175. Winn, supra note 171 , at $657-58$ (comparing the torts of invasion of privacy and breach of confidentiality).

176. Simson L. Garfinkel \& Abhi Shelat, Remembrance of Data Passed: A Study of Disk Sanitization Practices, IEEE Sec. \& PrIVACY, Jan.-Feb. 2003, at 17, 17-18.

177. Dan B. Dobbs, The Law of Torts 1392-93 (2000).

178. E. Haavi Morreim, The Clinical Investigator as Fiduciary: Discarding a Misguided Idea, 33 J.L. Med. \& Ethics 586, 586-98 (2005).

179. See Carl H. Coleman, Duties to Subjects in Clinical Research, 58 VAnd. L. Rev. 387, 425-26 (2005).

180. Id. 
Fiduciary theory may provide a less complex basis for suit than traditional negligence theory because the plaintiff would not need to prove all the elements of negligence, but the plaintiff would still have the burdens of proving that IRB members should be considered fiduciaries and of identifying their defined role. Some commentators have argued that the researcher-human subject relationship can be characterized as fiduciary. ${ }^{181}$ While fiduciary principles can be used as a starting point for analyzing the researcher-human subject relationship, ${ }^{182}$ there are a number of problems with actually characterizing investigators as fiduciaries. ${ }^{183}$ Most importantly, doing so fails to recognize that investigators do not have discretion in their decision-making concerning subjects - the research protocol determines treatment. ${ }^{184}$ Furthermore, investigators are not focused primarily on the interest of subjects. The fact that investigators have some obligations to subjects does not make them fiduciaries. ${ }^{185}$ Others have pointed out that the fiduciary model does not perfectly fit even treating physicians. ${ }^{186}$ In particular, physicians' obligations are often more extensive than simply promoting the individual patient's interests; they may also be responsible for promoting the general public's health and considering the best use of scarce resources.

The argument that IRBs owe a fiduciary duty to human subjects is even less convincing than the characterization of investigators as fiduciaries because IRB members are further removed from the traditional fiduciary model. IRBs have discretion in approving a protocol, but not in enrolling a particular subject. Moreover, they have responsibilities to the institution,

181. Id. at 433-34 (identifying commentators who argue for and against the characterization of researchers as fiduciaries).

182. Id. at 390 .

183. Morreim, supra note 42 , at $45-48$ (arguing that "the very nature of research precludes a fiduciary relationship between investigators and subjects" because the goal of research is not to promote the health of any particular human subject; however, when the investigator is also the participant's treating physician, she retains fiduciary duties). Subjects also tend to trust investigators who are not their treating physicians because they often suffer from "therapeutic misconceptions," believing that doctors, even those working solely as investigators and providing only experimental treatments, always have their best interests at heart. See Hoffman, supra note 70, at 758 (explaining the phenomenon of therapeutic misconception). Coleman stresses that the issue is not whether researchers are fiduciaries, but whether they are sufficiently similar to fiduciaries to be able to draw on fiduciary principles in describing investigators' obligations. Coleman, supra note 179 , at 435 .

184. Morreim, supra note 178 , at 587.

185. $I d$.

186. Marc A. Rodwin, Strains in the Fiduciary Metaphor: Divided Physician Loyalties and Obligations in a Changing Health Care System, 21 AM. J.L. \& MED. 241, 251-52 (1995) (explaining that health care professionals may be obligated to think in terms of overall public health, rather than simply the interests of a particular patient). 
responsibilities to the scientific community, and responsibilities to investigators, to name just a few. Obligations to specific subjects are limited and must be balanced against these other responsibilities. The bottom line is that plaintiffs will find it extremely difficult to establish that IRB members should be considered legal fiduciaries with respect to subjects and held to a fiduciary standard of decision-making.

\section{Defenses to Torts Suits}

The most significant obstacle to tort liability, regardless of the specific theory used, is the IRB's potential immunity to suit. ${ }^{187}$ There are two general types of immunity that may function in this context: governmental immunity and HCQIA immunity. Each will be addressed in detail below. In addition, there are also privilege statutes that may interfere with tort suits.

\section{Governmental Immunity}

If an IRB is associated with a public institution, such as a state hospital, a state university, or a Veterans Administration hospital, the IRB and its members may be protected against tort lawsuits by state or federal immunity statutes. ${ }^{188}$ Under the common law, the states and the federal government are shielded by sovereign immunity from tort actions. ${ }^{189}$ Immunity from tort

187. In the response to comments issued along with the original final regulations governing human subject research, both HHS and the FDA specifically rejected IRB immunity.

[HHS] is hesitant to require liability coverage because there is no certainty that feasible mechanisms are available to provide this protection. Furthermore, the Department is unaware of any successful negligence action which has named an IRB member as a defendant. It therefore believes that liability protection would be an unnecessary and costly requirement.

Final Regulations Amending Basic HHS Policy for the Protection of Human Research Subjects, 46 Fed. Reg. 8366, 8385 (Jan. 26, 1981).

FDA lacks the authority to grant limited liability to IRBs or their members. That authority resides in Congress and in the State legislatures. Although it is impossible to limit liability or to ensure against law suits, the agency believes that the chances for a successful suit against an IRB or its members are greatly diminished if the IRB has complied with these regulations and any applicable State law in reviewing the proposed research.

Protection of Human Subjects; Standards for Institutional Review Boards for Clinical Investigations, 46 Fed. Reg. 8958, 8961 (Jan. 27, 1981).

188. Bordas, supra note 143, at 150; Resnik, supra note 10, at 172-77.

189. Dan Dobbs \& Paul Hayden, Torts and Compensation 393 (2001) (explaining that the concept of sovereign immunity is a carryover from the English common law that established that " $[\mathrm{t}] \mathrm{he}$ King can do no wrong"). 
actions extends to federal and state agencies as well. ${ }^{190}$ However, most states have enacted laws that limit state sovereign immunity, ${ }^{191}$ and thus, a determination as to whether an IRB associated with a state or local governmental entity can be sued in state court for a tort will depend on the relevant state law.

Similarly, the federal government has generally waived its sovereign immunity under the Federal Tort Claims Act (FTCA). ${ }^{192}$ The FTCA, however, retains immunity for federal officials who execute their statutory or regulatory duties with due care and are sued in federal court. ${ }^{193}$ Immunity is also preserved for cases involving a "failure to exercise or perform a discretionary function or duty on the part of a federal agency or an employee of the Government" ${ }^{\prime 194}$ as well as for claims of assault, battery, misrepresentation, deceit, or interference with contract rights. ${ }^{195}$ These exceptions would seem to apply to IRBs associated with federal entities such as Veterans Administration hospitals that are sued for the negligent approval or monitoring of a challenged research protocol. Plaintiffs consequently are very unlikely to succeed in bringing tort cases against federal IRBs.

\section{Immunity Theories that Could Be Applied to Non-Governmental IRBs}

The FTCA and the state immunity statutes discussed above ${ }^{196}$ apply only to IRBs associated with public entities. No statute clearly grants immunity to IRBs that are associated with private institutions, but several doctrines might be extended to them if litigation becomes a common phenomenon and raises concerns among policymakers about the workability of the IRB system.

The Health Care Quality Improvement Act of 1986 (HCQIA) ${ }^{197}$ provides potential immunity for members of peer review committees who might be sued under either federal or state law. ${ }^{198}$ Immunity is extended to peer review activities that are reasonably calculated to promote quality health care and that meet particular notice and hearing provisions. ${ }^{199}$ Most commonly, peer review

190. Id.

191. Id. at 394 .

192. 28 U.S.C. $\S \S 2671-2680$ (2000).

193. Id. $\S 2680$ (a).

194. Id.

195. Id. \& 2680(h).

196. See supra Part IV.D.1.

197. 42 U.S.C. $\S \S 11101-11152$ (2000).

198. Id. $\S 11111$ (a)(1).

199. Id. $\S \S 11111(\mathrm{a})(1) \& 11112(\mathrm{a})$. 
committees are formed by hospitals to review physicians' applications for hospital privileges or requests for reappointment or additional privileges, ${ }^{200}$ but they are also used by state medical licensing boards to investigate physician disciplinary problems and by Medicare to assess quality of care. ${ }^{201}$ HCQIA was designed to encourage institutional use of peer review procedures and to facilitate recruitment of individuals to serve on peer review committees. ${ }^{202}$ As Congress becomes aware of heightened anxiety concerning potential litigation against IRBs, it might well decide to draft similar legislation to protect IRB members. ${ }^{203}$

At the state level, nearly all states and the District of Columbia have peer review protection statutes. ${ }^{204}$ These laws apply to good faith peer review proceedings and decisions and offer a range of immunities from civil liability. ${ }^{205}$ Furthermore, a few states have also considered the oversight activities of a different kind of health care review entity, the institutional ethics committee, ${ }^{206}$ and have enacted relevant legislation. ${ }^{207}$ Montana, for example, grants immunity to institutional ethics committee members so long as their activities are within the scope of their authority, they reasonably attempt to obtain necessary information, and they act without malice. ${ }^{208}$ Maryland provides immunity for "any action as a member of the medical review committee or for giving information to, participating in, or contributing to the function of the medical review committee."209 One might predict, consequently, that state legislators will respond to growing concerns about the

200. Nathaniel H. Hwang, Defaming a Physician's Career: The Double Edged Sword of Peer Review Privilege and Immunity, 25 J. Legal Med. 95, 101 (2004).

201. Saver, supra note 104, at 676 n.226.

202. See id.

203. For a recommendation that this be done, see infra Part VI.B.

204. Susan O. Scheutzow, State Medical Peer Review: High Cost but No Benefit—Is It Time for a Change?, 25 AM. J.L. \& MED. 7, 28 (1999). According to the article, only Michigan, Nebraska, and Nevada lack a peer review immunity statute. $I d$.

205. Id. at $28-30$

206. An ethics committee is a "[c]onsultative committee in a hospital or other institution whose role is to analyze ethical dilemmas and to advise and educate health care providers, patients, and families regarding difficult treatment decisions.” Office of TeCh. Assessment, U.S. Cong., Life-Sustaining TECHNOLOGIES AND THE ELDERLY app. h, 444 (1987), available at http://www.wws.princeton.edu/cgibin/byteserv.prl/ ota/disk2/1987/8714/871420.PDF (last visited Oct. 26, 2005).

207. Robin Fretwell Wilson, Hospital Ethics Committees as the Forum of Last Resort: An Idea Whose Time Has Not Come, 76 N.C. L. Rev. 353, 363-64 (1998).

208. Mont. Code Ann. §37-2-201(1) (2003).

209. Md. Code Ann., Health Occ. § 1-401(f)(1) (2005). 
threat of litigation that might compromise the integrity of IRB proceedings by creating parallel legislation to insulate IRB activities from liability. ${ }^{210}$

\section{Privileges}

In addition to immunity, states offer peer review committees a second kind of protection, namely, privilege. Privileges are evidentiary protections that "prevent certain information from being used in a legal case." 11 While no federal statute addresses the status of peer review deliberations, forty-eight states and the District of Columbia deem the proceedings of peer review committees to be privileged, though the scope of these statutes varies significantly. ${ }^{212}$ The statutes, intended to promote candid discussion among committee members and accurate record-keeping, generally establish that the records and deliberations of peer review committees are confidential and not subject to discovery. ${ }^{213}$ Perhaps not surprisingly, the question of privilege protection for IRB proceedings has already crossed the radar screen of the state courts. In a much-noted decision, Illinois applied its state peer review law to an IRB, preventing the plaintiffs from obtaining disclosure of their requested documents. ${ }^{214}$ Other states may follow Illinois' example in the future and would thereby severely obstruct the ability of plaintiffs to access the evidence necessary to construct cases against IRBs.

\section{E. Constitutional Claims}

Aggrieved human subjects might assert constitutional claims in addition to tort allegations if the IRB in question is associated with a public entity such

210. Haavi Morreim suggests the adoption of some form of immunity in her testimony before the Secretary's Advisory Committee on Human Research Protections on March 30, 2004. Draft of Summary Minutes of the Secretary's Advisory Committee on Human Research Protections, OHRP (Mar. 30, 2004), available at http://www.hhs.gov/ohrp/sachrp/mtgings/mtg03-04/mtg03-04.htm (last visited Oct. 26, 2005).

211. Jessica W. Berg, When, if Ever, Should Confidentiality Be Set Aside?, in Eтhical Dilemmas in Neurology 63 (Adam Zeman \& Linda Emanuel eds., 2000).

212. Scheutzow, supra note 204, at 33-34.

213. See Saver, supra note 104, at 676; Hwang, supra note 200, at 101.

214. Doe v. Ill. Masonic Med. Ctr., 696 N.E.2d 707, 711-12 (Ill. App. Ct. 1998)(holding that Illinois' peer review statute barred plaintiff from obtaining access to IRB records). But see MD. CoDE ANN., HEALTH-GEN. § 13-2003 (2005) (requiring IRBs to make meeting minutes available for inspection, though allowing IRBs to redact confidential and privileged information); Konrady v. Oesterling, 149 F.R.D. 592, 598 (D. Minn. 1993) (refusing to apply a state peer review statute to an IRB); Esdale v. Am. Cmty. Mut. Ins. Co., No. 94 C 4600, 1995 WL 263479 (N.D. Ill. May 3, 1995) (holding that IRB records are not privileged or confidential under federal law or regulation and, therefore, they can be accessed by the public). 
as a state hospital or university. Possible theories include violation of bodily integrity; deprivation of life, liberty or property without due process of law; or infringement of equal protection rights. ${ }^{215}$

Individual IRB members could also be sued for the same violations under Section $1983^{216}$ or under the Supreme Court's Bivens ${ }^{217}$ doctrine, which authorizes suit against federal officials. ${ }^{218}$ Section 1983 provides that "every person who, under color of any statute, ordinance, [or] regulation ... of any State . . . subjects . . . any citizen . . . to the deprivation of any rights, privileges, or immunities secured by the Constitution and laws, shall be liable to the party injured." ${ }^{219}$ The statute does not provide a cause of action against state entities themselves ${ }^{220}$ but can be an effective litigation vehicle against state officials who are challenged in their individual capacity. ${ }^{221}$

In Robertson v. McGee, ${ }^{222}$ for example, the plaintiffs alleged a Section 1983 claim for deprivation of their constitutional "right to be treated with dignity." While the claim was ultimately unsuccessful because the court refused to recognize a constitutional right to dignity, ${ }^{223}$ future plaintiffs invoking constitutional rights in cases of alleged IRB misconduct ${ }^{224}$ may achieve better outcomes in other courts.

215. Morreim, supra note 42 , at $74-75$.

216. 42 U.S.C. $\S 1983$ (2000).

217. See Bivens v. Six Unknown Named Agents, 403 U.S. 388, 395 (1971) (allowing for damages to redress Fourth Amendment violations by federal officials).

218. Bivens would be invoked in cases involving IRBs at federal institutions such as a VA hospital.

219. 42 U.S.C. $\S 1983$ (2000).

220. Lapides v. Bd. of Regents, 535 U.S. 613, 617 (2002) (asserting that states are not "persons" for purposes of $\S 1983$ ).

221. Mark R. Brown \& Kit Kinports, Constitutional Litigation Under § 1983, at 192 (2003).

222. No. 01-CV-60-C, 2002 U.S. Dist. LEXIS 4072, at*7 (N.D. Okla. Jan. 28, 2002). For a discussion of the case, see supra Part III.

223. The court found the claims to be unacceptably vague and unsupported by federal law. It found them to be "more appropriately state tort claims." 2002 U.S. Dist. LEXIS 4072, at *8.

224. Plaintiffs have already alleged constitutional violations in several research abuse cases in which IRBs were not named as defendants. See In re Cincinnati Radiation Litig., 874 F. Supp. 796, 810 (S.D. Ohio 1995) (claiming that the defendants, state and federal employees, deprived plaintiffs of the constitutional right to bodily integrity by subjecting them to experimental radiation treatments without consent); see also Heinrich ex rel. Heinrich v. Sweet, 62 F. Supp. 2d 282, 312 (D. Mass. 1999) (asserting that governmental defendants deprived the plaintiffs of the right to "bodily integrity, access to the courts, freedom from unlawful deprivations of property and unreasonable searches and seizures, and privacy" when they conspired to conduct medical experimentation on 140 terminally ill patients without consent). 
Plaintiffs asserting constitutional claims will face many of the hurdles described in the Torts section of this article. ${ }^{225}$ The most serious hurdle they will face, however, is the defense of governmental immunity.

First, the Eleventh Amendment provides that states cannot be sued in federal court. ${ }^{26}$ Eleventh Amendment immunity has been interpreted to extend to cases asserting constitutional claims in state court as well. ${ }^{227}$ Immunity also extends to agencies and other arms of the state, such as IRBs associated with state hospitals or universities. ${ }^{228}$ The amendment bars all suits for damages or retroactive relief against state governments that are sued by any party other than a different state or the federal government. ${ }^{229}$ Consequently, IRBs that are associated with state entities could not themselves be sued for constitutional violations. Likewise, the doctrine of federal sovereign immunity protects the United States from being sued without its consent. ${ }^{230}$ Consequently, IRBs associated with federal entities, such as Veterans Administration hospitals, could notbe sued for constitutional violations. By contrast, IRBs associated with county or city hospitals could be sued under federal law. Eleventh Amendment immunity does not extend to local government entities, ${ }^{231}$ and no other immunity provisions would apply to their IRBs.

Second, the defense of qualified immunity shields federal and state government officials who are performing discretionary functions from liability for civil damages unless their conduct violates "clearly established statutory

225. See supra Part IV.A (discussing the problems of proving the appropriate standard of care, causation, damages, and other issues).

226. U.S. Const. amend. XI. The text reads as follows: "The Judicial power of the United States shall not be construed to extend to any suit in law or equity, commenced or prosecuted against one of the United States by Citizens of another State, or by Citizens or Subjects of any Foreign State." Congress can abrogate the states' sovereign immunity, but only if it passes legislation under Section 5 of the Fourteenth Amendment, which gives it "power to enforce [that Amendment] by appropriate legislation." BROWN \& KinPORTS, supra note 221, at 196. The Eleventh Amendment does not protect local governmental entities, which are suable under $\S 1983$. Monell v. N.Y. City Dept. of Soc. Servs., 436 U.S. 658, 690 (1978).

227. Alden v. Maine, 527 U.S. 706, 712 (1999) (holding that "the powers delegated to Congress under Article I of the United States Constitution do not include the power to subject nonconsenting States to private suits for damages in state courts").

228. Edelman v. Jordan, 415 U.S. 651, 663 (1974); Ford Motor Co. v. Dep’t of Treasury, 323 U.S. 459, 463-64 (1945).

229. John E. NowaK \& Ronald D. Rotunda, Constitutional Law 49 (6th ed. 2000); Alden, 527 U.S. at 754 .

230. 4 Charles Alan Wright, Arthur R. Miller \& Edward H. Cooper, Feder al Practice and Procedure: JuRisDiction $§ 3654$ (3d ed. 1998 \& Supp. 2005).

231. Monell, 436 U.S. at 690. 
or constitutional rights of which a reasonable person would have known." ${ }^{232}$ Consequently, individual governmental actors can be held liable only if they could be expected to have known that their actions would result in a violation of constitutional rights. ${ }^{233}$ Proving such knowledge is difficult, but not impossible.

In In re Cincinnati Radiation Litigation ${ }^{234}$ the plaintiffs asserted that the defendants, state and federal employees, had deprived them of their constitutional right to bodily integrity by subjecting them to experimental radiation treatments to which they did not consent. ${ }^{235}$ The plaintiffs, terminally ill cancer patients, were never told that the radiation doses they received were designed to develop data concerning potential nuclear attacks for the Defense Department and did not constitute standard therapy. ${ }^{236}$ The court rejected the defendants' claim of qualified immunity, holding that they should have known that their abusive conduct was constitutionally offensive. $^{237}$ Accordingly, in egregious cases, plaintiffs should be able to defeat claims of qualified immunity. In many other cases, however, with some proof of a good faith effort to comply with the federal regulations, defendants will enjoy immunity protection even in the face of harmful research outcomes.

\section{F. False Claims Act}

A more creative but fairly limited approach to some IRB litigation involves the False Claims Act (FCA). ${ }^{238}$ The FCA allows for civil damages

232. Harlow v. Fitzgerald, 457 U.S. 800, 818 (1982); see also Davis v. Scherer, 468 U.S. 183, 191 (1984) (stating that "[w]hether an official may prevail in his qualified immunity defense depends upon the objective reasonableness of [his] conduct as measured by reference to clearly established law").

233. Harlow, 457 U.S. at 819; see also Davis, 468 U.S. at 191. If the plaintiff fails to allege a violation of clearly established law in the complaint, the defendant will be entitled to dismissal of the suit prior to the commencement of discovery under Federal Rule of Civil Procedure 12(b)(6). See In re Cincinnati Radiation Litig., 874 F. Supp. 796, 808 (S.D. Ohio 1995) ("[B]efore the commencement of discovery, a defendant asserting qualified immunity is entitled to dismissal if the plaintiff fails to state a claim alleging the violation of clearly established law.").

234. 874 F. Supp. at 796.

235. $I d$. at 818 .

236. Id. at 803 .

237. $I d$. at 822 (holding that the defendants treated the plaintiffs "as though they were laboratory animals," subjecting them to "deliberate and calculated exposure ... to harmful medical experimentation without their informed consent").

238. 31 U.S.C. $\S \S 3729-3733$ (2000); see Daniel J. Powell, Comment, Using the False Claims Act As A Basis for Institutional Review Board Liability, 69 U. CHI. L. Rev. 1399 (2002) (advocating use of the FCA in IRB litigation). Defendants are fined between $\$ 5,000$ and $\$ 10,000$ plus three times the amount of damages which the government sustains because of the act of that person for each false claim that is filed. 
against anyone who "knowingly makes, uses, or causes to be made or used, a false record or statement to get a false or fraudulent claim paid or approved by the Government." ${ }^{239}$ Private citizens can bring qui tam actions ${ }^{240}$ on behalf of the government ${ }^{241}$ if they can show the requisite knowledge on the part of the defendant or that the defendant acted with deliberate ignorance or reckless disregard of the truth. ${ }^{242}$ Qui tam plaintiffs can receive up to thirty percent of the damages. ${ }^{243}$

Thus, if the IRB votes to approve or continue a clinical trial that is funded by a governmental agency or department knowing that regulatory compliance has not been achieved or that sufficient information was not available to justify its decision, the IRB could be deemed to have obtained payment from the government for research in violation of the FCA. Theoretically, plaintiffs may experience more success under the FCA than under traditional tort doctrine because they need not prove personal injury or causation. ${ }^{244}$ They must prove only fault on the part of the IRB.

Nevertheless, the possibility of success in such cases will often be remote because plaintiffs will have to show that the IRB knew the research violated the federal regulations but still approved it or that the IRB basically "rubberstamped" approval of the protocol. ${ }^{245}$ Furthermore, IRBs do not themselves submit grant applications or research proposals to the government and do not have direct contact with funding entities. They merely approve and monitor projects that are proposed and conducted by investigators. Consequently, it might be difficult to establish that the IRB presented a false or fraudulent claim or caused such a claim to be presented to the government in violation of the FCA.

31 U.S.C. § 3729(a) (2000).

239. 31 U.S.C. § 3729(a)(2) (2000); see also id. § 3729(a)(1) (establishing that "anyone who knowingly presents, or causes to be presented, to an officer or employee of the United States Government ... a false or fraudulent claim for payment or approval" is liable to the U.S. government).

240. Qui tam actions are actions "brought under a statute that allows a private person to sue for a penalty, part of which the government or some specified public institution will receive.” BLACK's LAW DiCTIONARY 1282 (8th ed. 2004).

241. 31 U.S.C. $\$ 3730(b)(2000)$.

242. Id. $\S 3729(\mathrm{~b})$.

243. Id. §3730(d)(1)-(2) (2000).

244. See Powell, supra note 238, at 1416.

245. Id. 


\section{Policy Considerations}

Thus far, we have analyzed several different types of causes of action along with the corresponding practical obstacles to litigation against IRBs. The latter include the need to prove the applicable standard of care, injury, and causation as well as the availability of immunity defenses for IRBs associated with public institutions and the existence of immunity and privilege statutes for other health care oversight entities that could be extended to apply to IRBs. ${ }^{246}$ Despite these potential limitations, we still believe that litigation has a role to play in this context. We now turn to a discussion of a variety of policy considerations that are relevant to the debate about the usefulness of IRB litigation.

\section{A. Arguments Against IRB Liability}

\section{Who Will Want to Serve On An IRB?}

The most serious concern about the potential for liability is its effect on research institutions' abilities to recruit members for IRB service. ${ }^{247}$ In the vast majority of IRBs, members volunteer their time, receiving no payment or relief from other institutional duties. ${ }^{248}$ If lawsuits against IRBs become a common phenomenon, it is unlikely that volunteers would be willing to risk personal liability in addition to accepting the time commitment and workload required by IRB service. ${ }^{249}$ Concern about retention and recruitment of IRB members is likely to be such that research entities will be tempted to settle with disgruntled human subjects regardless of the merits of their claims.

Concern about potential litigation is particularly acute for community representatives. ${ }^{250}$ Unlike health care professionals, who are often sued in

246. See supra Part IV.

247. Anderlik \& Elster, supra note 4, at 225.

248. See supra note 52 and accompanying text.

249. Anderlik \& Elster, supra note 4, at 225. The authors include the following quote from Gary Chadwick, executive director of the institutional review board at the University of Rochester:

Why would I even want to risk the chance of being named in a lawsuit? ... With the amount of research done at any major research university or academic medical center, there will be people who have adverse events ... and there will be no more IRBs and there will be no more research because you can't do research without IRBs. Id.

250. According to the federal regulations, each IRB must have at least one member with nonscientific expertise. 21 C.F.R. $\S 56.107$ (c) (2005); 45 C.F.R. § 46.107(c) (2005). However, some advocates are urging that IRBs include many more community representatives. See supra notes 146-47 and 
malpractice cases, lay IRB members otherwise may have no exposure to legal claims. Furthermore, the extent to which malpractice insurance is available in this context is currently unclear. ${ }^{251}$ Even if IRB members ultimately receive malpractice insurance coverage or indemnification, the prospect of being named as a defendant is extremely unappealing. Regardless of the ultimate outcome of the case, defendants would be subject to discovery, depositions, and often, negative media attention.

It should be noted that traditional IRBs are at times being displaced by a relatively new entity, the independent or for-profit IRB. A small number of IRBs now operate independently, as private entities, reviewing research that is sponsored by industry and conducted outside a university or hospital setting. ${ }^{252}$ According to one source, as of 1999, two to three percent of IRBs were for-profit, commercial enterprises. ${ }^{253}$ Other sources estimate that in 2000 , as few as twenty-two ${ }^{254}$ or as many as fifty to sixty independent IRBs existed. $^{255}$ These entities reportedly review anywhere from 24 to 1,500 protocols per year. ${ }^{256}$ For-profit IRBs consist of paid experts who operate on a fee-for-service basis. ${ }^{257}$ Thus, commercial research sponsors are charged for the service of having their proposals assessed by an IRB, and each IRB member is a paid professional. Career IRB reviewers are less likely to be deterred from service by the threat of litigation than are their volunteer counterparts, since risk of liability would be viewed as an expected job-related hazard, as is the case for doctors, lawyers, and many other professionals.

accompanying text.

251. Morreim, supra note 210. In her testimony, Professor Morreim states that she knows of only two insurers offering policies that clearly cover IRBs, and these are far from comprehensive. See supra note 102 and accompanying text.

252. Human Subject Research Protections, supra note 64 (testimony of William F. Raub, Ph.D., Deputy Assistant Sec'y for Science Policy, Department of Health and Human Services); see also Coleman, supra note 8 , at 7 (noting that a significant amount of research "takes place in nonacademic settings, including private physicians' offices").

253. D. Christian Addicott, Regulating Research on the Terminally Ill: A Proposal for Heightened Safeguards, 15 J. Contemp. Health L. \& Pol'y 479, 506 (1999).

254. Trudo Lemmens \& Alison Thompson, Noninstitutional Commercial Review Boards in North America: A Critical Appraisal and Comparison with IRBs, 23 IRB: ETHICs \& Hum. Res. 1, 2 (2001). The article reports the results of an extensive survey concerning noninstitutional commercial review boards in the United States and Canada.

255. Richard Rettig, Drug Research \& Development: The Industrialization of Clinical Research, 19 Health AfFs., 129, 139 (2000).

256. Lemmens \& Thompson, supra note 254 , at 4.

257. Testimony of Raub, supra note 252. 


\section{The Dangers of Over-Deterrence}

A second concern is that IRBs might be so anxious about litigation that they become loath to approve any research project at all, ${ }^{258}$ demanding excessive amounts of information and repeated reassurances from investigators about the safety of each protocol. Severe delays could significantly retard the development of lifesaving treatments and would not be in society's best interest. This phenomenon would be analogous to the practice of "defensive medicine," whereby physicians order costly, unnecessary tests and treatments simply as a form of insurance against legal liability. ${ }^{259}$

The temptation to postpone or deny protocol approval unnecessarily, however, might be counteracted by other pressures. Like human subjects, investigators could also bring legal challenges against IRBs and might do so if they believe IRBs have, without sufficient basis, refused to provide timely approval of their protocols, thereby damaging their careers. ${ }^{260}$ These types of lawsuit are likely to be rare and may be difficult to win, but the possibility of their initiation might induce IRBs to achieve an appropriate balance between efficiency and thoroughness of deliberation.

A related issue is the possibility that the specter of litigation might influence the content of IRB deliberations. ${ }^{261}$ Members might, for example, hesitate to make candid statements regarding their reactions to particular protocols for fear of later discovery, and deliberations might be driven as much by a desire to build a defense to potential litigation as by the duty to protect human subjects. Limitations on liability for decisions made in good faith should minimize this risk.

\section{Cost}

Finally, frequent litigation against IRBs will raise the costs of research and development. Costs will be generated by pre-trial and trial proceedings as well as by the need to provide IRBs with comprehensive insurance, to the

258. Anderlik \& Elster, supra note 4, at 225; Powell, supra note 238, at 1418.

259. Noah, supra note 9, at 213-14; Resnik, supra note 10, at 179.

260. See AMdUR \& BANKERT, supra note 102, at 343 (discussing lawsuits brought by investigators); Noah, supra note 9, at 213-14; Resnik, supra note 10, at 179; see also Philip Hamburger, The New Censorship: Institutional Review Boards, 62004 Sup. Cт. Rev. 271, 343-50 (analyzing whether the federal regulations concerning IRBs give rise to First Amendment claims).

261. See Resnik, supra note 10, at 180. 
extent that this is not already done. ${ }^{262}$ Furthermore, the cost of review charged by for-profit IRBs would likely rise, as those entities seek to pass on their additional liability or insurance costs to the institutions using their services. Some study sponsors might agree to indemnify IRBs or research institutions in case of lawsuits, but they too will likely shift their costs, presumably to consumers.

\section{B. Arguments in Favor of Liability}

The prospect of frequent litigation against IRBs raises profound concerns that the IRB system, which relies heavily on the work of volunteers, will find itself fundamentally threatened. ${ }^{263}$ Nevertheless, several potent arguments suggest that increased legal challenges to IRB activity might produce positive social outcomes. In particular, liability will serve as a check against the failure of professional ethical standards, as it does in the traditional treatment context. $^{264}$ Moreover, the potential for liability may promote professionalism. ${ }^{265}$ The following sections explore in detail the specific advantages of recognizing IRB liability.

\section{Promoting Enhanced Review Activity}

First, a meaningful risk of liability could promote more careful reviews by IRBs and more responsible decision-making. ${ }^{266}$ The deterrent effect of liability might be particularly important in the IRB context because there are no market forces at work to create proper incentives. With the exception of for-profit IRBs, ${ }^{267}$ IRBs derive no direct financial gain from their work and, therefore, cannot enhance their earnings by developing a reputation for

262. See supra notes 102,251 and accompanying text.

263. See supra Part V.A.1.

264. See supra Part II.D (discussing conflicts of interest and professionalism). Some authors suggest that an increase in malpractice is evidence of the failure of professionalism. See, e.g., Susan Daicoff, Asking Leopards to Change Their Spots: Should Lawyers Change? A Critique of Solutions to Problems with Professionalism by Reference to Empirically-Derived Attorney Personality Attributes, 11 Geo. J. LeGAL ETHiCs 547 (1998).

265. Jeffrey H. Rutherford, Comment, Dziubak v. Mott and the Need to Better Balance the Interests of the Indigent Accused and Public Defenders, 78 Minn. L. Rev. 977, 1009 (1994).

266. See Anderlik \& Elster, supra note 4, at 225 (stating that " $[\mathrm{t}]$ he threat of liability may strengthen [IRB members'] . . . commitment to protecting subjects even at the expense of their relationships with colleagues" who could have their protocols more often rejected or revised); Resnik, supra note 10, at 181-82 (asserting that "lawsuits can lead to changes in behavior, as well as legal reforms").

267. See supra notes 252-56 and accompanying text. 
extraordinarily diligent and thorough reviews. ${ }^{268}$ Moreover, human subjects, the real beneficiaries of IRB review and the ones whose lives are at stake, have no control over the selection of the IRB that will oversee their studies. Investigators submit protocols to IRBs ${ }^{269}$ long before human subjects have been recruited and are involved in the project.

While IRBs are subject to federal oversight, governmental supervision of IRB activities ranges from extremely deficient to almost nonexistent. HHS and the FDA have the power to conduct inspections and impose penalties upon IRBs for misconduct. ${ }^{270}$ In reality, however, these agencies have limited resources and only a minimal ability to inspect and evaluate the work of IRBs. There are between 3,000 and 5,000 IRBs in the United States. ${ }^{271}$ Between June 1998 and March 2000, OPRR (now OHRP) conducted on-site investigations at only ten institutions ${ }^{272}$ and off-site document reviews at an

268. Ironically, in fact, some of those served by IRBs, namely investigators, might resent enhanced scrutiny of protocols because it would increase the likelihood of rejection by the IRB or requests for revision and resubmission.

269. Typically, investigators automatically submit their protocols to an IRB associated with the research institution at which they are employed or to a for-profit IRB.

270. Each research institution must provide the federal agencies with written assurance of compliance with the federal regulations. 21 C.F.R § 56.115(a) (2005); 45 C.F.R. $\S ~ 46.103$ (a) (2005). Each research entity or IRB must also prepare and maintain detailed documentation regarding IRB activities, including continuing reviews. 21 C.F.R $\S 56.115$ (b); 45 C.F.R. $\S 46.115$ (a). These records must be maintained for at least three years after completion of the study and must be made available to federal agency personnel for inspection and copying, if requested. 45 C.F.R. $\S 46.115$ (b). The FDA regulations specify the penalties that may be imposed on an IRB or research institution for noncompliance with regulatory requirements. 21 C.F.R $\$ \$ 56.120-121$. These range from a demand for corrective action and reinspection to termination of ongoing studies or even disqualification of the IRB or parent institution. 21 C.F.R $\S 56.120(a)$, (b)(1), (b)(3); $\$ 56.121$. The regulations do not authorize a federal agency to impose fines or penalties on individual IRB members. However, the FDA asserts that it may at any time initiate criminal or civil action against an IRB or research entity through the Department of Justice or may refer matters to other federal, state, or local agencies for appropriate action. 21 C.F.R § 56.124.

271. 2000 OIG REPORT, supra note 2 , at 20 . The majority are associated with hospitals and academic institutions. Other IRBs exist in managed care organizations, government agencies, or as independent forprofit entities. $I d$. at 20-21. Because there is no central registry of IRBs, it is impossible to ascertain their exact number. Burman et al., supra note 2 , at 152 . To address this, the FDA recently proposed a new rule which would require all IRBs to register at an HHS website. Institutional Review Boards; Registration Requirements, 69 Fed. Reg. 40556 (proposed July 6, 2004).

272. Human Subjects in Medical Research: Hearing Before the Subcomm. on Criminal Justice, Drug Policy and Human Resources of the H. Comm. on Government Reform, 106th Cong. (2000) [hereinafter Grob, Human Subjects in Medical Research] (testimony of George Grob, Deputy Inspector General for Evaluation and Inspections, Department of Health and Human Services), available at $2000 \mathrm{WL}$ 543556. The OHRP site visits are primarily for cause, though once a year OHRP may conduct such a visit without cause. See National Advisory Bioethics Advisory Commission, Ethical and Policy Issues in Research Involving Human Participants, available at http://www.bioethics.gov/reports/past_commissions/ nbac_human_part.pdf (last visited Oct. 26, 2005). 
additional 140 research entities. ${ }^{273}$ OPRR found performance problems at a number of these institutions and required seven to suspend part or all of their federally funded research. ${ }^{274}$ One can only imagine how many violations the federal government would have found had it inspected many more IRBs.

Without adequate governmental oversight and without economic inducements for high performance, the IRB system might be sorely in need of the incentive of legal liability. Tort law, for example, has been described as a "market regulator" that promotes public safety because it makes "injury producing activities or goods more expensive than their safer competitors."275 While many regulatory agencies suffer from insufficient resources and personnel needed to adequately design rules, monitor behavior, and prosecute violators, tort law has an almost limitless enforcement mechanism in the form of private litigation brought by any party who perceives herself to be injured. ${ }^{276}$

It should be noted, however, that commentators disagree about the effectiveness of tort liability as a deterrent to misconduct, and the empirical literature provides only weak evidence in this regard. ${ }^{277}$ Some have argued that tort law fails to deter undesirable behavior because its sanctions are perceived as weak, it does not clearly articulate what conduct will be punished, much of the activity that is sanctioned cannot be changed through monetary disincentives, ${ }^{278}$ and it discourages innovation and, therefore, actually retards social progress. ${ }^{279}$ Critics also claim that moral principles provide a much stronger incentive for appropriate behavior than does tort law. ${ }^{280}$ This might be particularly true in the case of IRB members, who

273. Grob, Human Subjects in Medical Research, supra note 272.

274. $I d$.

275. Peter A. Bell \& Jeffrey O’Connell, Accidental Justice: The Dilemmas of Tort Law 73 (1997).

276. Id. at 97.

277. Id. at 68 (noting that recently, "scholars, 'reformers,' and even some judges have expressed skepticism about whether tort awards have any significant deterrent value"); Jerry L. Mashaw, Causation and Financial Compensation: A Comment on Causation, Law Reform, and Guerilla Warfare, 73 Geo. L.J. 1393, 1394 (1985) (stating that "it is extremely difficult to find any empirical evidence that the tort system produces deterrence in the sense normally talked about"); Frank A. Sloan et al., Effects of Tort Liability and Insurance on Heavy Drinking and Drinking and Driving, 38 J.L. \& Econ. 49, 72 (1995) (asserting that "[ $\mathrm{t}] \mathrm{here}$ is a paucity of empirical evidence on deterrent effects of tort law").

278. This might be so because the behavior is subconscious, the threat of sanctions is too remote, or the actors have too great an interest in continuing the conduct. See BeLl \& O'Connell, supra note 275, at $86-87$.

279. See id. at 77-78.

280. See Gary T. Schwartz, Reality in the Economic Analysis of Tort Law: Does Tort Law Really Deter?, 42 UCLA L. REV. 377, 382 (1994). 
typically volunteer their services and know that they are charged with the duty of safeguarding the welfare of human subjects. In addition, the deterrent effect of tort law is vitiated by the availability of liability insurance. ${ }^{281}$

Other commentators, however, point to studies indicating that the tort system influences conduct to a limited extent, reducing malpractice by less than thirty percent and negligent driving by approximately ten percent. ${ }^{282}$ In the words of one commentator, "tort law, while not as effective as economic models suggest, may still be somewhat successful in achieving its stated deterrence goals." ${ }^{283}$ Others have stressed the need for additional empirical research and suggest ways to increase the deterrent effect of medical malpractice litigation. ${ }^{284}$

\section{Elucidating Oversight Standards}

Another potential benefit of litigation is the elucidation of the federal regulatory standards. As noted above, the regulatory language leaves many questions unanswered. ${ }^{285}$ Such ambiguities are not uncharacteristic of statutory and regulatory text, which is often the product of political compromise and, therefore, is frequently imprecise or unclear. ${ }^{286}$ In the process of negotiation and public comment, strong wording that would have provided greater clarity might be abandoned in order to make the regulations palatable to a larger number of parties. In the alternative, gaps may exist in

281. Id. at 385 .

282. Id. at 444; see also Paul C. Weiler, Medical Malpractice on Trial 91 (1991) (arguing that tort law has stimulated "broad-based improvements in the institutional environment and procedures through which medical care is provided").

283. Schwartz, supra note 280 , at 443 ; see also Richard A. Posner, Alternative Compensation Schemes and Tort Theory: Can Lawyers Solve the Problems of the Tort System?, 73 CAL. L. Rev. 747, 749 (1985) (referring to studies that "show that liability insurance premiums affect the decision to drive [and] that the number of automobile deaths has risen as a result of the no-fault movement (perhaps by as much as $15 \%$ in some states)").

284. Michelle M. Mello \& Troyen A. Brennan, Deterrence of Medical Errors: Theory and Evidence for Malpractice Reform, 80 Tex. L. Rev. 1595 (2002).

285. See supra notes $138-42$ and accompanying text.

286. See Joseph Tussman \& Jacobus tenBroek, The Equal Protection of the Laws, 37 CAL. L. REv. 341,350 (1949) (stating that "[e]verything that emerges from the legislative forum is tainted by its journey through the lobby"); see also ANTONIN SCALIA, A MATTER OF INTERPRETATION 34-35 (1997) (discussing the role of lawyer-lobbyists and arguing that, because of their involvement, legislative history is not an appropriate tool for statutory interpretation); Chai R. Feldblum, Definition of Disability Under Federal Anti-Discrimination Law: What Happened? Why? And What Can We Do About It?, 21 Berkeley J. EmP. \& LAB. L. 91, 126-34 (2000) (discussing the politics of the Americans with Disabilities Act's passage). 
the federal guidelines simply because their drafters could not anticipate all circumstances and issues that would arise.

Litigation, consequently, might achieve a significant clarification of the standards with which IRBs must comply. Courts will resolve disputes on a case-by-case basis, thereby setting relevant precedent that will serve future parties seeking guidance. ${ }^{287}$

On the other hand, some might object that litigation is not the best vehicle for regulatory clarification and that a better approach would be to revise and strengthen the regulations themselves or to implement some type of accreditation process that incorporates clear standards. ${ }^{288}$ Lawsuits are factspecific, and the decisions they produce might not be sensible as general rules to be applied to a broad range of factual circumstances. Moreover, different courts may decide similar cases differently, leading to more confusion than clarification. Furthermore, litigation depends on the willingness of injured parties to invest money and effort in bringing claims and the willingness of lawyers to incur opportunity costs and stake their reputations on litigating particular cases. If litigation is the sole corrective measure, it is possible that fairly minor issues will be extensively litigated, while far more significant regulatory gaps will be ignored. ${ }^{289}$ Nevertheless, at least some case law precedent will be generally applicable to future controversies, even if the universe of issues addressed is incomplete.

287. See Charles F. Hart, Interpreting the Heightened Pleading of the Scienter Requirement in Private Securities Fraud Litigation: The Tenth Circuit Takes the Middle Ground, 80 Denv. U. L. Rev. 577, 582 (2003) (explaining that after the passage of the Private Securities Litigation Reform Act, litigation was necessary "to resolve various ambiguities in the statute and clarify many of the Act's procedural requirements"); see also Laura Carlan Battle, A Transnational Perspective on Extending NEPA: The Convention on Environmental Impact Assessment in a Transboundary Context, 5 DuKE ENVTL. L. \& PoL'Y F. 1, 11 (1995) (stating that litigation has elucidated the application of the National Environmental Policy Act within the United States, but not its applicability abroad).

288. An Institute of Medicine (IOM) report describes three implementation phases of an accreditation process. Phase two involves the development of clear standards. IOM, Preserving the Public Trust: Accreditation and Human Research Participant Programs (2001). There are some private entities that have begun accrediting IRBs and research institutions, such as the Association for the Accreditation of Human Research Protection Programs (AAHRPP). Id.; see AAHRPP Home Page, http:// www.aahrpp.org.

289. See Resnik, supra note 10, at 182 (noting that, arguably, litigation is “'hit or miss' and ad hoc ... [b]ecause attorneys often bring lawsuits in a haphazard fashion"). 


\section{Promoting Social Dialogue and Social Justice}

Litigation can also promote public dialogue concerning important social issues, especially if it attracts media attention. Regulatory oversight occurs behind the scenes, in meetings that are closed to the public, prior to the involvement of human subjects. ${ }^{290}$ High-profile cases could capture public attention, raise awareness of oversight problems, and generate open debate concerning the regulatory standards. ${ }^{291}$ Public pressure, in turn, could lead to positive changes in the form of regulatory revisions or more careful enforcement of the regulations by IRBs. It might also be accompanied by a willingness to invest more resources in IRB administration and training of IRB members. In addition, public dialogue could educate Americans about biomedical research, possibly enlarging the pool of interested participants and better preparing potential human subjects to understand and evaluate study enrollment options.

Finally, one might argue straightforwardly that if an IRB is partly responsible for abuse or injury to human subjects, it should be held legally responsible. ${ }^{292}$ Our legal system couples duty with liability, and IRBs should not escape the consequences of misconduct.

\section{Recommendations}

We have outlined above the advantages and disadvantages of litigation against IRBs. ${ }^{293}$ It is also clear that lawsuits against IRBs are not inconceivable and may be an increasingly common phenomenon. ${ }^{294}$ The question to which we now turn is how such litigation against IRBs should be structured. Options include an administrative review process that would precede any court action, qualified immunity protection, and the granting of privileged status to IRB deliberations and records. Each of these will be analyzed below.

290. See 45 C.F.R. $\S \S 46.108-.109$ (2005) (describing IRB meetings and review of research).

291. See Resnik, supra note 10, at 181 (stating that "attorneys can help set the agenda for public policy debate").

292. See Anderlik \& Elster, supra note 4, at 225.

293. See supra Part V.

294. See supra notes 123-24 and accompanying text. 


\section{A. Preliminary Administrative Review}

Litigation against IRBs could promote more careful protocol reviews and other positive social changes. ${ }^{295}$ A system based solely on prospective review of research projects is inadequate because of limited resources ${ }^{296}$ and because it does not provide for remedies when abuse occurs. Nevertheless, since traditional IRBs rely on the service of volunteers, and all IRB work requires candid debate, ${ }^{297}$ the system may be unable to survive if IRB members are frequently sued when subjects are dissatisfied with research outcomes.

Similar concerns are raised in the context of professional peer review activities, ${ }^{298}$ and two states have adopted strategies that should be imported into the arena of IRB operations. New York and Colorado have implemented statutes that establish administrative review procedures, without which plaintiffs cannot turn to the courts. ${ }^{299}$

Under the New York law, physicians who believe they have been wronged with respect to hospital staff appointments or professional privileges must first file a complaint with the New York Public Health Council (PHC), which investigates the allegations. ${ }^{300}$ If the PHC finds that the claim is meritorious, it may instruct the hospital to reconsider its adverse decision against the physician. ${ }^{301}$ After the PHC review, the aggrieved physician can initiate a court action for injunctive or monetary relief. ${ }^{302}$ While the records of PHC proceedings remain confidential, ${ }^{303}$ its findings of fact constitute prima facie (though not conclusive) evidence for later court proceedings. ${ }^{304}$

Likewise, Colorado requires administrative review of physician claims of unreasonable anti-competitive conduct associated with privileges or staff

295. See supra Part V.B.

296. See supra Parts II.A \& B.

297. See supra Parts V.A.1 \& 2.

298. See supra notes 200-01 and accompanying text.

299. Craig W. Dallon, Understanding Judicial Review of Hospitals' Physician Credentialing and Peer Review Decisions, 73 Temp. L. Rev. 597, 674-76 (2000); Colo. Rev. Stat. § 12-36.5-106(1), (7), (10) (2004); N.Y. Pub. Health LaW § 2801-b (McKinney 2002 \& Supp. 2005).

300. N.Y. Pub. Health LaW $\S 2801-b(2)$.

301. Id. § 2801-b(3).

302. Id. § 2801-c (McKinney 2002); Gelbard v. Genesee Hosp., 664 N.E.2d 1240, 1242 (N.Y. 1996) (explaining that plaintiffs have an initial opportunity to present their claims to the PHC and can subsequently bring their cases before the courts).

303. N.Y. Pub. Health Law $\S 2801-b(3)$.

304. Id. $\S 2801-\mathrm{c}$; Gelbard, 664 N.E.2d at 1241 (stating that "PHC's findings are accorded only presumptive, not conclusive, effect"). 
membership. ${ }^{305}$ A state statute establishes the Committee on Anticompetitive Conduct, composed of five members of whom four must be licensed to practice medicine and be actively doing so. ${ }^{306}$ The Committee is authorized to reverse or revise the hospital's decision, dismiss the complaint, or require the hospital board to conduct a further review of the case. ${ }^{307}$ Following the Committee's assessment, the aggrieved individual can seek appellate review by either the state's court of appeals or de novo review in a district court. ${ }^{308}$

In addition, some states subject medical malpractice claims to prescreening by medical review panels prior to allowing state court action. ${ }^{309}$ For example, under Indiana's Medical Malpractice Act, claimants must file their proposed complaints with the Department of Insurance and wait for the issuance of an opinion by a medical review panel. ${ }^{310}$ According to one source, twenty states utilized screening panels as of $2003 .^{311}$

Mandated initial administrative review is not purely a state invention. In the area of employment discrimination, the federal anti-discrimination statutes mandate such review before plaintiffs can utilize the federal court system. Under Title VII of the Civil Rights Act of 1964 (Title VII), the Age

305. Colo. Rev. Stat. § 12-36.5-106(7) (2004). Physician claims not alleging anticompetitive conduct may be taken directly to the courts. See id. §12-36.5-106(8).

306. Id. § 12-36.5-106(2).

307. Id. § 12-36.5-106(9)(k)-(m).

308. Id. § 12-36.5-106(10)(a)-(b).

309. See Conn. Gen. Stat. Ann. §§ 38a-32-38a-33 (West 2000) (providing that "[w]henever all parties to a claim for malpractice agree, they may request the Insurance Commissioner or his designee to select a panel composed of two physicians and one attorney from the Malpractice Screening Panel"); IDAHO Code AnN. § 6-1001 (2004) (mandating the creation of hearing panels that provide prelitigation consideration to medical malpractice claims); 24 Me. REv. STAt. ANN. tit. 24, § 2852 (2000) (detailing procedures for prescreening panels); John J. Fraser, Jr. \& Committee on Medical Liability, Technical Report: Alternative Dispute Resolution in Medical Malpractice, 107 Pediatrics 602, 604 (2001) (discussing pretrial screening panels and asserting that "[a]bout half of the states have statutes establishing pretrial screening panels that review malpractice claims and render a nonbinding advisory opinion on the merits of the claim before a suit being filed"); see also Jack M. Beermann, Why Do Plaintiffs Sue Private Parties Under Section 1983?, 26 CARdozo L. REv. 9, 25 (2004) (stating that "there are procedural impediments to asserting medical malpractice claims in many state courts, such as case screening by a medical panel"); Stephen N. Subrin \& Thomas O. Main, The Integration of Law and Fact in an Uncharted Parallel Procedural Universe, 79 Notre Dame L. Rev. 1981, 2012 (2004) (stating that "[m]any states require that a full law/fact narrative, including expert testimony, be presented to a screening panel prior to commencing medical malpractice cases").

310. Ind. Code ANN. § 34-18-8-4 (LexisNexis 1998).

311. See Catherine T. Struve, Pew Project on Med. Liab. in Pa., Expertise in Medical Malpractice Litigation: Special Courts, Screening Panels, and Other Options 57 (2003), available at $\mathrm{http}: / /$ medliabilitypa.org/research/struve1003/StruveReport.pdf (last visited Oct. 26, 2005). The report also found that screening panel provisions were repealed or invalidated in thirteen states that originally adopted them. Id. 
Discrimination in Employment Act (ADEA), and the Americans with Disabilities Act (ADA), aggrieved individuals must exhaust their administrative remedies before turning to the federal courts. ${ }^{312}$ They must file a charge of discrimination with the Equal Employment Opportunity Commission (EEOC) and await either the agency's determination on the merits or a right to sue letter. ${ }^{313}$

A parallel approach should be adopted for claims against IRBs, utilizing OHRP and FDA inspections. OHRP has oversight authority over institutions engaged in human subject research that is conducted or supported by HHS, ${ }^{314}$ while the FDA has oversight authority over clinical studies designed to develop new drugs, medical devices, and biological products, such as vaccines and blood substances. ${ }^{315}$ OHRP and FDA reviews should be mandatory for all matters over which these entities have authority and should precede judicial review. ${ }^{316}$ These agencies would review claims filed by subjects to determine whether the federal regulations were violated. Currently, the FDA and OHRP evaluate all written complaints that they receive concerning IRB conduct, whether they are submitted by human subjects, investigators, or other individuals. ${ }^{317}$ However, no formal system is in place by which human subjects are informed of the investigatory functions of the FDA or OHRP or

312. See 29 U.S.C. § 626(d) (2000); 42 U.S.C. § 2000e-5(e)-(f) (2000); see also 42 U.S.C. § 12117 (2000) (adopting the procedures set forth under Title VII, 42 U.S.C. $\$ 2000 \mathrm{e}-5$, for the enforcement of the ADA).

313. See sources listed supra note 312. A right to sue letter does not in itself imply that the claim is meritorious. See 42 U.S.C. $\S 2000$ e-5(f)(1) (2000) (discussing the ability of charging parties to obtain the right to sue letter if the EEOC has not taken action within 180 days after the charge of discrimination was filed).

314. See Memorandum from Greg Koski, OHRP Director, to OHRP Staff regarding Compliance Oversight Procedures (Dec. 4, 2000), available at http://www.hhs.gov/ohrp/humansubjects/guidance/a ohrpcomp.pdf (last visited Oct. 26, 2005) [hereinafter Koski].

315. See 21 C.F.R. § 50.1(a) (2005); see also FDA Home Page, http://www.fda.gov (last visited Oct. 26, 2005) (describing, inter alia, all items regulated by the FDA).

316. Inevitably, there will be studies that fall outside the scope of HHS and FDA jurisdiction because they do not involve drugs or devices, are sponsored by private industry, and are conducted outside of covered institutions, such as by private practitioners. Allegations of abuse in these cases would not be subject to OHRP review and would go directly to the courts. See Morreim, supra note 42, at 62 (indicating that some clinical research is not subject to federal regulation).

317. OHRP —Compliance Oversight, http://www.hhs.gov/ohrp/compliance (stating that the Division of Compliance Oversight "evaluates all written substantive allegations or indications of noncompliance with the HHS regulations" and, if appropriate, "requires corrective action by the institution") (last visited Oct. 26, 2005); see also FDA-Reporting Complaints Related to FDA-Regulated Clinical Trials, http://www.fda.gov/oc/gcp/complaints.html (providing contact information) (last visited Oct. 26, 2005). 
of their right to contact the offices, ${ }^{318}$ and aggrieved parties are not required to seek administrative determinations prior to filing suit.

In order to implement a mandatory review system, it is likely that a network of local offices, similar to EEOC district offices, ${ }^{319}$ will need to be established in order to distribute the workload and to provide greater accessibility to aggrieved individuals. Currently, the OHRP office is located only in Rockville, Maryland, ${ }^{320}$ but HHS, of which OHRP is a part, has ten regional offices. ${ }^{321}$ The FDA Office for Regulatory Affairs lists field offices in approximately twenty locations. ${ }^{322}$ These regional offices could include officials with the authority to investigate and issue opinions concerning research abuse claims. Individuals who believe they have been injured by IRB actions would be required to submit written complaints, under oath or affirmation, through the mail or in person, with or without the assistance of an attorney. ${ }^{323}$ Following the EEOC model, OHRP and the FDA could be required to investigate complaints within a limited amount of time, and if no determination is made before the deadline, the aggrieved party could request a right to sue. ${ }^{324}$

If it finds regulatory noncompliance, OHRP has authority to order the offending institution to take corrective action; to suspend research projects; to recommend the temporary or permanent removal of investigators or entire institutions from specific studies or from all HHS-supported research; and to

318. Interview with Kathleen Lawry, Institutional Review Board Manager, MetroHealth Medical Center, in Cleveland, Ohio (July 31, 2004).

319. See 42 U.S.C. $\S 2000 \mathrm{e}-4$ (f) (2000) (empowering the EEOC, headquartered in the District of Columbia, to "establish such regional or State offices as it deems necessary to accomplish" its purpose). According to the EEOC website, it has fifteen district offices, fifteen area offices, twelve local offices, and nine field offices. See EEOC Field Offices, http://www.eeoc.gov/offices.html (last visited Oct. 26, 2005).

320. See OHRP —Contact Information, http://www.hhs.gov/ohrp/about/index.html/\#contact (last visited Oct. 26, 2005).

321. See HHS Region Map, http://www.hhs.gov/about/regionmap.html (last visited Oct. 26, 2005). The regional offices are located in Boston, New York, Philadelphia, Atlanta, Chicago, Dallas, Kansas City, Denver, San Francisco, and Seattle.

322. ORA Field Directory, http://www.fda.gov/ora/inspect_ref/iom/iomoradir.html (providing the Office of Regulatory Affairs field directory) (last visited Oct. 26, 2005).

323. See generally 42 U.S.C. $\S 2000$ e-5(b) (2000) (requiring that charges of discrimination "shall be in writing under oath or affirmation"); N.Y. Pub. Health LAW $§ 2801-b(2)$ (McKinney $2002 \&$ Supp. 2005) (stating that aggrieved physicians must file written, verified complaints with the public health council, by themselves or through their attorneys, as a prerequisite to litigation). The appropriate forms could be made available through agency websites.

324. 42 U.S.C. $\$ 2000 \mathrm{e}-5(\mathrm{f})(1)$ (2000) (allowing the EEOC 180 days within which to investigate a charge of discrimination, after which time a charging party must be allowed to sue on his or her own behalf). 
order special reviews, reporting, and training. ${ }^{325}$ Upon an adverse finding, the FDA has authority to prohibit new subjects from being enrolled in a trial or to disqualify an IRB or an institution. ${ }^{326}$ The FDA may also ask the Department of Justice to institute civil or criminal proceedings against an offending entity or refer matters to appropriate federal, state, or local government agencies, ${ }^{327}$ all of which can presumably be done by OHRP as well.

Neither OHRP nor the FDA can order institutions to pay damages to injured research participants. ${ }^{328}$ Consequently, even with a positive OHRP or FDA finding, human subjects might wish to turn to the courts for monetary relief and should not be barred from doing so. ${ }^{329}$ In all cases, the subject should be able to request permission to move forward with a lawsuit if the agency has not made a determination within a designated time period. ${ }^{330}$ Once an administrative complaint is filed, the statute of limitations should be tolled for any subsequent lawsuits, thus enabling subjects to litigate after the agency determination. Plaintiffs could be required to file complaints with the agency within a limited period after the alleged wrong occurred ${ }^{331}$ and to file suit within a specified time after receiving the agency's determination. ${ }^{332}$

The agencies' factual findings should constitute prima facie evidence for subsequent court proceedings, though such evidence would not be conclusive. ${ }^{333}$ A negative finding or one of minor infractions should discourage litigation. However, the fact that a subject would still be able to sue provides protection against deficient and superficial agency evaluations.

325. See generally Koski, supra note 314.

326. 21 C.F.R. §§ 56.120-.121 (2005) (describing "Administrative Actions for Noncompliance"). The regulations do not provide for judicial review of such decisions.

327. 21 C.F.R. $\S 56.124$ (2005)

328. See supra notes 321-23 and accompanying text.

329. See N.Y. Pub. Health Law $\S 2801$-c (McKinney 2002) (allowing for court actions after review by New York's PHC); Gelbard v. Genesee Hosp., 664 N.E.2d 1240, 1242 (N.Y. 1996) (explaining that plaintiffs have an initial opportunity to present their claims to the PHC and can subsequently bring their cases before the courts).

330. See, e.g., Title VII, 42 U.S.C. § 2000e-5(f)(1) (2000) (allowing the EEOC 180 days within which to investigate a charge of discrimination, after which time a charging party must be allowed to sue on his or her own behalf).

331. See, e.g., id. $\S 2000 \mathrm{e}-5(\mathrm{e})(1)$ (requiring aggrieved individuals to file charges of discrimination under Title VII within either 180 days or 300 days of the adverse employment action, depending on the circumstances)

332. See, e.g., id. $\S 2000 \mathrm{e}-5(\mathrm{f})(1)$ (requiring plaintiffs to file suit within 90 days of receiving a right to sue letter from the EEOC).

333. See N.Y. Pub. Health LaW § 2801-c (McKinney 2002); Gelbard, 664 N.E.2d at 1242 (stating that "PHC's findings are accorded only presumptive, not conclusive, effect"). 
A positive finding would not lead to automatic liability but would provide a basis for suit should the subject choose to pursue the matter. While the agency's final determination would be sent to all parties, other records would be disclosable only in a manner consistent with the privacy provisions of the FDA regulations that protect "[p]ersonnel, medical, and similar files",334 and the Freedom of Information Act. ${ }^{335}$

In order to render the mandatory administrative review system workable and effective, all human subjects enrolled in OHRP or FDA-governed trials must be informed of their right to initiate complaints with the relevant agency and be given contact information for the appropriate regional office. This information could be included with a copy of the informed consent document or other literature that is given to each human subject. ${ }^{336}$ The requirement would be similar to the notice obligation imposed by Title VII on all employers. ${ }^{337}$ Each employer is required to post notices concerning the law's anti-discrimination mandate and procedures for filing a charge of discrimination in prominent places that are accessible to employees. ${ }^{338}$

\section{Benefits of Administrative Review}

Preliminary agency review prior to the filing of lawsuits would serve a variety of purposes and address some of the central concerns relating to IRB litigation. First, the system would filter out many frivolous cases, because attorneys could not simply add IRBs to a long list of defendants at no cost. Instead, they would have to go through a separate administrative process for

334. 21 C.F.R. $\S 20.63$ (2005); see also 21 C.F.R. $\S 20.20$ (2005) (describing the "[p]olicy on disclosure of Food and Drug Administration records").

335. 5 U.S.C. $§ 552$ (b) (2000) (listing nine categories of information that cannot be disclosed, including "personnel and medical files and similar files the disclosure of which would constitute a clearly unwarranted invasion of personal privacy").

336. Some research institutions provide potential study participants with easy-to-read brochures about clinical research. See, e.g., Dep't of Veterans Affs., I'm a Veteran. Should I Participate in Research? Here Are Some Things You NEED to Know (pamphlet on file with the authors). All research entities would be wise to follow this example and provide user-friendly, accessible material to those considering becoming human subjects.

337. 42 U.S.C. $\S 2000 \mathrm{e}-10$ (a) (2000).

338. Id. The provision reads:

Every employer ... shall post and keep posted in conspicuous places upon its premises where notic es to employees, applicants for employment, and members are customarily posted a notice to be prepared or approved by the Commission setting forth excerpts from or, summaries of, the pertinent provisions of this subchapter and information pertinent to the filing of a complaint. 
IRB claims. Furthermore, plaintiffs' attorneys who receive an adverse agency determination may choose not to pursue the claim in court. ${ }^{339}$

Second, investigations will generally escape public and media scrutiny, at least until a determination is made,${ }^{340}$ since, unlike court proceedings, they will not involve the filing of publicly available pleadings. Consequently, IRB members will most likely be shielded from adverse publicity relating to abuse accusations during the agency investigation and may never be hailed into court if no misconduct is found by the FDA or OHRP. This should ease concerns about recruitment of IRB members.

For claims that do not involve serious physical or mental injury, the agency review process might serve as an efficient and low-cost vehicle for resolution. For example, human subjects who are dissatisfied with recruitment or informed consent procedures might be content with an opportunity to register their complaints and a call for corrective action on the part of the research institution at issue. Plaintiffs who do not seek substantial monetary damages may be pleased to avoid the cost and other burdens of prolonged court proceedings. ${ }^{341}$ Consequently, administrative review may function as the sole remedial avenue for plaintiffs who cannot pursue their cases under state tort law because of proof problems ${ }^{342}$ and as the primary deterrent of negligent conduct that does not result in substantial compensable damages. $^{343}$

A requirement of administrative review should not excessively burden either the federal government (FDA and OHRP) or aggrieved parties. Since 2001, only five cases have been filed in court against IRB defendants. ${ }^{344}$ Furthermore, litigation outcomes are not encouraging for plaintiffs' attorneys

339. Under the proposal, the agencies' factual findings would constitute prima facie (though not conclusive) evidence for subsequent court proceedings.

340. See 42 U.S.C. $\$ 2000$ e-5(b) (2000) (providing that charges of discrimination "shall not be made public" by the EEOC). But see 21 C.F.R. $\$ 56.122$ (2005) (providing that "[a] determination that the Food and Drug Administration has disqualified an institution and the administrative record regarding that determination are disclosable to the public").

341. See Dallon, supra note 299, at 675 (noting that New York's PHC "plays an important mediation role" in peer review disputes).

342. See supra Part IV (discussing potential causes of action against IRBs and the difficulties plaintiffs might face in proving them).

343. Mello \& Brennan, supra note 284, at 1633-34 (suggesting that "by introducing an administrative mechanism through which avoidable injuries can be compensated more swiftly and accurately ... the proposed system thereby increases certainty, and thus deterrence"). Mello and Brennan's article focuses on modifying the malpractice liability system to achieve better deterrence. Among other recommendations, they advocate "an insurer-based administrative system to identify and compensate the subset of adverse events that are avoidable."). Id. at 1628.

344. Resnik, supra note 10, at 134-35. 
because IRB members have never been found liable. ${ }^{345}$ Consequently, it is unlikely that an overwhelming number of claims would be filed with administrative agencies. Even if the number of cases increases significantly in the coming years, it will not reach proportions that will deluge the two agencies.

Aggrieved individuals would not be charged for administrative reviews and, therefore, would not incur additional costs associated with the procedure. ${ }^{346}$ Furthermore, the requirement will not significantly delay substantial relief for aggrieved human subjects since they will, in the interim, be able to pursue their claims against the investigators and research institutions involved in the challenged research study. An agency finding of oversight inadequacies might, in fact, facilitate resolution of cases by inducing at-fault parties to settle early or to offer injured subjects financial recovery before suit is filed. For subjects who are economically or socially disadvantaged ${ }^{347}$ no-cost administrative review that does not require the hiring of a lawyer may be the only accessible avenue for redress. ${ }^{348}$

\section{Concerns About Administrative Review}

There has been much written about the limitations of the EEOC system in the employment discrimination context, including suggestions that the system be revamped to allow private lawsuits without agency intervention. ${ }^{349}$ However, the proposed review system will differ from the EEOC's in significant ways and, thus, should avoid many of the problems that are perceived to exist in the employment discrimination arena.

First, unlike Title VII of the Civil Rights Act, the proposed system does not require the creation of a new regulatory entity. The agencies at issue here (HHS and FDA) are already tasked with research oversight functions. ${ }^{350}$ The

345. Id. at 183 .

346. OHRP and FDA reviews of complaints, like EEOC investigations, are publicly financed.

347. 45 C.F.R. § 46.111(3) (2005) (mandating equitable subject selection, including "vulnerable populations" and "economically or educationally disadvantaged persons").

348. Some of the lawsuits may be accepted on a contingency fee basis. In these cases there may be less of a barrier due to the plaintiff's socioeconomic status than due to whether the lawsuit is expected to result in a large settlement or verdict (which would affect the amount of the contingency fee).

349. See, e.g., Michael Selmi, The Value of the EEOC: Reexamining the Agency's Role in Employment Discrimination Law, 57 Онго Sт. L.J. 1 (1996).

350. See, e.g., Sana Loue, Textbook of Research Ethics: Theory and Practice 171-75; 185-88 (2000) (describing both HHS (through the Office for Human Research Protections-OHRP) and FDA efforts to monitor compliance with the federal regulations and review allegations of research misconduct). 
proposal formalizes the requirements for administrative review and makes it a mandatory first step for potential litigants. It does not enlarge government or add to the federal bureaucracy.

Second, the proposal should not generate a significant number of otherwise nonexistent lawsuits and produce troubling case backlogs. ${ }^{351}$ The establishment of the EEOC corresponded with the enactment of Title VII, creating new causes of action and opening the floodgates of employment discrimination litigation. By contrast, as discussed in Part IV, there are limited grounds for lawsuits in the research area. Additionally, the EEOC process has led to a great deal of litigation about the administrative process itself. ${ }^{352}$ The fact that the FDA and HHS already have a process in place to evaluate complaints about research misconduct makes the possibility that there will be additional litigation regarding these procedures less likely. Moreover, based on EEOC precedent, we can determine at the outset controversial issues such as "particular time-frames for filing a claim [and] ... the weight to be accorded a cause or no cause determination." ${ }^{353}$ As a result, many of the administrative problems encountered in the EEOC context may be avoided.

Third, one of the initial complaints about the EEOC was that it lacked any enforcement power. ${ }^{354}$ As a result, in 1972 Congress amended Title VII to allow the EEOC to sue in federal court. ${ }^{355}$ By contrast, the FDA and HHS already have significant enforcement power. They may halt one or all experiments ongoing at an institution, require specific remedial steps, and even halt all federal funding for an investigator or an entire institution. ${ }^{356}$ The FDA and HHS have additional powers that may provide more effective remedies than those available by court order in certain cases. The agencies can alter research and review standards nationwide if the need for such

351. See Kathryn Moss et al., Unfunded Mandate: An Empirical Study of the Implementation of the Americans With Disabilities Act by the Equal Employment Opportunity Commission, 50 U. KAN. L. Rev. 1,5 (2001) (reporting the results of a study that shows that the EEOC's lack of funding results in an unfair process, criticizing the administrative review process for that reason, and observing that " $[t]$ o make tens of thousands of people who believe they have suffered employment discrimination file an administrative charge without receiving an adequate investigation is unjust and serves no valid purpose").

352. Selmi, supra note 349 , at 10 .

353. $I d$.

354. Maurice E. R. Munroe, The EEOC: Pattern and Practice Imperfect, 13 YALE L. \& PoL'y Rev. 219, 249 (1995); Selmi, supra note 349, at 5-6.

355. Munroe, supra note 354, at 219. Munroe argues that the EEOC should no longer evaluate individual complaints, but would more effectively combat employment discrimination by investigating employers who show statistical evidence of discrimination in hiring practices. Id. at 275.

356. See supra notes 325-27 and accompanying text. 
changes becomes apparent. ${ }^{357}$ District court decisions, by contrast, generally apply only to the parties involved in the case and do not constitute binding precedent for cases arising in other jurisdictions. Consequently, administrative review could significantly enhance regulatory compliance.

Fourth, administrative review may be more beneficial in the research context than in the employment discrimination context. While there are numerous attorneys with employment discrimination expertise, there are few lawyers trained in research law and ethics. Thus, there may only be a few members of the private bar who are able to evaluate potential research abuse cases and who are equipped to litigate them. ${ }^{358}$ The availability of an administrative review process will make it possible for subjects to be heard, and agency findings of misconduct will encourage private attorneys to become familiar with the relevant legal doctrines and to pursue meritorious claims.

Finally, HHS and FDA would not become parties to any subsequent lawsuit. Unlike the EEOC, the two agencies would not be authorized to intervene in lawsuits, ${ }^{359}$ but would simply provide an initial investigation and review. The EEOC's litigation duties require significant funding and time. Giving this responsibility to HHS and FDA would take away from their core roles of setting oversight standards and approving new drugs and devices. Moreover, it may unnecessarily create antagonistic relations between the agencies and the institutions they regulate. HHS and FDA need to be able to work comfortably with these institutions to maintain safety standards and should not be engaged in litigation. Furthermore, information must be shared freely in the early stages of investigations of new products, and the potential for future litigation may hinder that process. We leave open the possibility that HHS or FDA should play a role as a conciliator or facilitator in settling litigation. ${ }^{360}$ For example, HHS recently announced a pilot settlement program for cases in which the agency finds merit in patient claims of

357. Since the agencies create the regulations governing research oversight, they can change them or interpret them as appropriate to address pervasive problems. For a description of the regulatory framework, see, e.g., BERG ET AL., supra note 85, at 249-58.

358. See, e.g., Selmi, supra note 349, at 27-46 (suggesting that attorneys need a degree of expertise in the relevant legal area to evaluate whether or not a case is worthwhile to pursue).

359. See Charles B. Craver, The Use of Non-Judicial Procedures to Resolve Employment Discrimination Claims, 11 KAN. J.L. \& PuB. PoL'y 141, 165 (2001) (criticizing the current EEOC system and suggesting that the EEOC adopt procedures like those used by the NLRB to resolve employment discrimination claims).

360. The EEOC has the authority to conciliate cases. 42 U.S.C. $\S 2000 \mathrm{e}-5$ (b) (2000); 29 U.S.C. $\S$ 626(b) (2000); see also Title VII of the Civil Rights Act of 1964 Charges: FY 1992-FY 2005, http://www.eeoc.gov/stats/enforcement.html (last visited Oct. 26, 2005). 
malpractice relating to federally funded community health centers or the Indian Health Service. ${ }^{361}$

\section{B. Immunity and Privilege}

Under the proposal outlined above, parties would be allowed to initiate suit in state or federal court after the exhaustion of administrative remedies. Moreover, for some cases, the IRB in question will not come under the authority of the FDA or HHS, ${ }^{362}$ and litigation will be the first line of attack for injured subjects. The question remains: Should IRBs and IRB members enjoy any further protection beyond the gatekeeping function of the OHRP and the FDA? Below we evaluate two types of protections that traditionally function within the litigation process - qualified immunity and privilege. We conclude that IRBs should be granted qualified immunity from suit but that the content of IRB deliberations should not be granted any special evidentiary privilege.

\section{Qualified Immunity}

Federal lawmakers have grappled with concerns about litigation in the similar context of peer review disputes and have designed an effective solution - qualified immunity. HCQIA ${ }^{363}$ provides immunity from civil damages for professional review bodies, ${ }^{364}$ individual members or staff of the review bodies, those under contract or formal agreements with those bodies, and those assisting with or participating in the review process. ${ }^{365}$ The

361. Tanya Albert, HHS Pilots Way to Quicker Settlements, 47 Am. Med. News, Oct. 11, 2004, at 5-6, available at http://www.ama-assn.org/amednews/2004/01104.htm (registration required) (last visited Oct. 26, 2005). The "early offers" program will allow both the claimant and HHS to submit a proposed settlement amount to a third-party administrator within 90 days of the filing of the claim. If the claimant makes an offer of settlement and its amount is equal to or lower than the agency's, the claim is settled. All the information provided by each side to the third-party administrator is kept confidential, including the fact that the party has made a settlement offer. Only if the above-described conditions are met and settlement is reached will the third-party administrator notify both sides. The program addresses malpractice in government-funded health centers. In the research context, HHS might play the role of the third-party administrator, following a similar model.

362. See supra note 42 and accompanying text.

363. 42 U.S.C. $\S \S 11101-11152(2000)$.

364. Id. § 11151(11) (A "professional review body" is defined as "a health care entity and the governing body or any committee of a health care entity which conducts professional review activity, and includes any committee of the medical staff of such an entity when assisting the governing body in a professional review activity").

365. Id. § 11111(a)(1). 
immunity, which extends to hospitals as well, ${ }^{366}$ applies to both state and federal damages actions arising from any professional review action. ${ }^{367}$ HCQIA carves out exceptions for civil rights cases, to which immunity does not extend. ${ }^{368}$

HCQIA immunity, moreover, is limited to cases in which certain procedural and substantive requirements have been met. The challenged action must be taken with a reasonable belief that it advances health care quality after reasonable fact-gathering efforts have been made, after the physician involved has been afforded adequate notice and hearing opportunities, and with a reasonable belief that the challenged action is justified by the facts of the case. ${ }^{369}$

An immunity statute based on the HCQIA model should be enacted to protect IRBs and IRB members who are sued in conjunction with research oversight activities. These entities should not be held liable for damages so long as they have fulfilled certain substantive and procedural obligations. The IRB must have had a good faith belief that, in making the challenged decision, it was protecting the welfare of human subjects to be enrolled in the study. It must not have violated any of the regulatory guidelines concerning approval of protocols. ${ }^{370}$ For example, the IRB will not be immune if it improperly expedited a protocol, approved a study without a majority vote, voted without a quorum present at the meeting, failed to consider the risks of the study or the adequacy of planned informed consent procedures, or failed to conduct annual continuing reviews. ${ }^{371}$ However, if it properly deliberated the relevant criteria $^{372}$ and voted on the protocol in good faith, the IRB will not be found blameworthy even if the court disagrees with the IRB's substantive decision to approve the study.

This approach is consistent with the business judgment rule that protects corporate board decisions. The business judgment rule insulates from liability

366. See Scheutzow, supra note 204 , at 30.

367. 42 U.S.C. $\S 11151(10)$ (2000) (A "professional review activity" is defined as any activity of a health care entity "(A) to determine whether the physician may have clinical privileges with respect to, or membership in, the entity, (B) to determine the scope or conditions of such privileges or membership, or (C) to change or modify such privileges or membership").

368. Id. § 11111(a)(1).

369. Id. § 11112 (a).

370. See 21 C.F.R. $\S 56.108-.111$ (2005); 45 C.F.R. $\S \S 46.108-.111$ (2005) (detailing procedures for IRB review of research).

371. See 21 C.F.R. $\S \S 56.108-.111 ; 45$ C.F.R. $\$ \S 46.108-.111$ (detailing procedures for IRB review of research).

372. See 21 C.F.R. $\S 56.111 ; 45$ C.F.R. $\S 46.111$. 
directors who make business decisions with a good faith belief that the decisions are in the corporation's best interest, so long as no conflict of interest exists and sufficient information was gathered in the process. ${ }^{373}$ Consequently, in making negligence determinations, courts applying the rule focus on the processes used by the boards rather than on the substantive merits of the decisions. ${ }^{374}$

As in the case of HCQIA, the IRB immunity rule should not extend to cases alleging violation of civil or constitutional rights because of the overwhelming public interest in combating these wrongs, ${ }^{375}$ though IRB members sued under Section 1983 would enjoy qualified immunity pursuant to constitutional doctrine. ${ }^{376}$ For all other cases, such as negligence claims, however, a HCQIA-modeled immunity rule would achieve an appropriate balance between deterrence of misconduct and preserving the integrity of the IRB system.

IRBs and IRB members would be assured that so long as they followed proper procedures for protocol review and deliberated in good faith, they would not be liable for civil damages and would be dismissed from cases as soon as their good faith and regulatory compliance were verified. ${ }^{377}$ IRBs would not have their scientific expertise discounted and their decisions second-guessed by lay juries or judges. On the other hand, human subjects would be able to obtain redress in cases of egregious wrongdoing, such as a failure to vote on a protocol prior to approval or to monitor the progress of a study. Furthermore, if administrative review did not produce sufficient corrective measures, the courts would be able to provide injunctive relief to prevent future research abuses at the institution in question.

373. See Saver, supra note 104, at 667, 672 \& n.174 (citing Smith v. Van Gorkom, 488 A.2d 858, 872 (Del. 1985)).

374. Id. at 667 n.196 (citing Lynn A. Stout, In Praise of Procedure: An Economic and Behavioral Defense of Smith v. Van Gorkom and the Business Judgment Rule, 96 Nw. U. L. REv. 675, 681 (2002) (explaining that courts eschew second-guessing the substantive merits of business decisions because they are "extraordinarily complex, opaque, and uncertain")).

375. 42 U.S.C. § 11111(a)(1) (2000); Austin v. McNamara, 979 F.2d 728, 733 (9th Cir. 1992) (stating that HCQIA does not cover $\S 1983$ or Title VII claims); LeMasters v. Christ Hosp., 791 F. Supp. 188, 191 (S.D. Ohio 1991) (emphasizing that the Act does not apply to civil rights actions).

376. See supra Part IV.E.

377. See Scheutzow, supra note 204, at 32 (noting that some courts have refused to dismiss peer reviewers pursuant to HCQIA immunity provisions and forced trials "even where there is no objective evidence of improper peer review activity" and explaining that in the face of court recalcitrance, HCQIA has thus had inconsistent efficacy (quoting Frederic J. Entin, General Counsel for the American Hospital Association)). 
The promise of qualified immunity, coupled with preliminary administrative review, would provide substantial protection to IRB members, and recruitment of volunteers should not become impossible even in the face of more frequent litigation against IRBs. While for-profit IRBs that pay generous salaries for protocol reviews are likely to attract members regardless of litigation statistics, immunity should extend to these entities as well. ${ }^{378}$ The recommended immunity provisions would encourage open, candid debate of issues on all IRBs and responsible decision-making that does not include gratuitous steps designed solely to establish defenses in case of legal challenge. ${ }^{379}$

Some states provide immunity for peer review activities that is stronger than that offered by HCQIA because it shields the conduct of committees even in the face of procedural shortcomings. ${ }^{380}$ A comprehensive study of state immunity statutes found that stronger provisions failed to enhance peer review activities or to encourage committees to scrutinize physician qualifications more carefully. The study concluded that "[i]n fact, in the controlled analysis, hospitals in states with medium level immunity statutes were less likely to report adverse actions [denying physicians staff privileges] than hospitals in states with no immunity." ${ }^{381}$ Immunity that extends beyond HCQIA protection and does not require some procedural and substantive safeguards is not recommended for IRBs. ${ }^{382}$

\section{Privilege}

Although HCQIA does not establish a peer review privilege, most states offer a degree of protection for peer review information. ${ }^{383}$ A study of state peer review privilege statutes found that these statutes, like the very strong state immunity laws, did not bolster the peer review process. ${ }^{384}$ The study

378. One lawsuit had already listed Western IRB (an independent IRB) as a defendant. Robertson Complaint, supra note 120. For a discussion of the case, see supra notes 118-22 and accompanying text.

379. See supra Part V.A.2.

380. See Scheutzow, supra note 204, at 32 (discussing "the absence of procedural requirements at the state level").

381. Id. at $47-48$.

382. See Wilson, supra note 207, at 405 (arguing that hospital ethics committees should not generally be insulated from liability but that HCQIA offers a reasonable approach because it "exacts a price for the immunity it affords - notice and opportunity to be heard, representation by an attorney and written determination, among others").

383. Scheutzow, supra note 204, at 33-34.

384. Id. at 49. 
emphasized that in most areas of the law, privileges are increasingly disfavored because they potentially obstruct justice by hindering the ability of plaintiffs to build their cases. ${ }^{385}$ Congress consciously declined to establish statutory privilege protection for peer review deliberations in HCQIA. ${ }^{386}$

Privilege doctrine, in fact, may be conceptually inappropriate in the peer review and IRB contexts, because it is generally established only in order to protect and encourage certain relationships, such as those between spouses, attorneys and clients, or therapists and patients. ${ }^{387}$ The relationships in which IRBs are involved are less personal, are not characterized by confidential communications that public policy should seek to protect, and will not be jeopardized by the potential for disclosure. Furthermore, in order to determine whether IRBs made decisions in good faith and in compliance with regulatory guidance for purposes of granting qualified immunity, the courts would need access to IRB minutes, ${ }^{388}$ tapes of meetings, and IRB personnel who could be interviewed. Consequently, IRB deliberations and records should not be protected by privilege.

\section{CONCLUSION}

Time will tell whether there will be a significant increase in the volume of cases brought against IRBs and IRB members. New developments, such as the creation of no-fault compensation funds for research injuries, would decrease the likelihood of lawsuits. ${ }^{389}$ Even without such funds, thus far the

385. Id. at 49,53 .

386. Id. at 51 .

387. Id. at 49-50 (citing 8 Wigmore ON Evidence $\S 2285$, at 527 (3d ed. 1940)). Wigmore's explanation of common law privilege doctrine has been described as follows:

First, the communications must originate in a confidence that they will not be disclosed. Second, this element of confidentiality must be essential to the full and satisfactory maintenance of the relation between the parties. Third, the relation must be one that in the opinion of the community should be diligently fostered. And fourth, the injury that would inure to the relationship by the disclosure of the communications must be greater than the benefit thereby gained for the correct disposal of litigation.

Scheutzow, supra note 204, at 49-50.

388. The federal regulations specifically describe the records that IRBs must keep. See 21 C.F.R. $\S 56.115$ (2005); 45 C.F.R. $\S 46.115$ (2005).

389. See President's Comm’n for the Study of Ethical Problems in Med. and Biomedical and Behavioral Research, Compensating for Research Injuries: The Ethical and Legal Implications of Programs to Redress InJuRed Subjects (1982) (suggesting that the creation of such funds be explored); Larry D. Scott, Research-Related Injury: Problems and Solutions, 31 J.L. MeD. \& Eтнісs 419, 420 (2003) (describing the University of Washington's no-fault compensation fund for research injuries). 
phenomenon has been a rarity, and no plaintiff has yet been successful in suing an IRB. ${ }^{390}$ Nevertheless, many have noted that the prospective review system by which IRBs review an often overwhelming number of protocols each year with little oversight from federal agencies is inadequate to safeguard the welfare of human subjects. ${ }^{391}$ Alan Milstein, an attorney who has filed several lawsuits against physician investigators and IRB defendants on behalf of clinical trial participants, has asserted that IRBs share the blame for alleged injuries to human subjects, and he will undoubtedly continue to name them in lawsuits. In one article he stated that, "[i]n our major institutions, where you've got Nobel scientists and Nobel doctors and well-regarded professors, the IRBs more or less simply rubber-stamp whatever protocol one of these men put before them." ${ }^{392}$

It may well be that prospective reviews must be coupled with retrospective actions that respond to negligence and intentional research abuses in order to bolster human subject protection. This article has explored the difficulties of litigation against IRBs and the advantages and disadvantages of such litigation from a social policy perspective. It has suggested a system of administrative reviews followed by litigation subject to a qualified immunity defense in order to provide incentives for diligent and conscientious IRB work without undermining the viability of the IRB system.

Frequent litigation could have a profound effect on the biomedical research community and, therefore, we cannot delay thinking about how it should be addressed. It is crucial that federal policymakers respond to the emerging phenomenon of legal challenges against IRBs with measured and thoughtful mechanisms to preserve both the welfare of human subjects and the integrity of the oversight system.

390. Resnik, supra note 10, at 183.

391. See, e.g., A Time FOR REFORM, supra note 9, at ii (concluding that "IRBs are reviewing too much, too quickly, with too little expertise”); Office of Inspector Gen., DeP't of Health and Human Servs., Protecting Human Subjects Research: Status of Recommendations 17 (2000), available at http://org.hhs.gov/oci/reports/oci-01-97-00197.pdf (last visited Oct. 26, 2005) (finding that few of the reforms suggested in the OIG report had been implemented and that legislative reform may be necessary).

392. Vida Foubister, Lawsuits Have Doctors Wary, But Not Quitting Research Yet, 44 AM. Med. News 1, 1 (2001). 